\title{
Transmission dynamics of methicillin-resistant Staphylococcus aureus in pigs
}

\section{Florence Crombé ${ }^{1,2}{ }^{*}{ }^{\dagger}$, M. Angeles Argudín ${ }^{1 \dagger}$, Wannes Vanderhaeghen ${ }^{1,2}$, Katleen Hermans $^{2}$, Freddy Haesebrouck ${ }^{2}$ and Patrick Butaye ${ }^{1,2}$}

${ }^{1}$ Department of Bacterial Diseases, Veterinary and Agrochemical Research Centre, Brussels, Belgium

${ }^{2}$ Department of Pathology, Bacteriology and Avian Diseases, Faculty of Veterinary Medicine, Ghent University, Ghent, Belgium

\section{Edited by:}

Axel Cloeckaert, Institut National de la Recherche Agronomique, France

Reviewed by:

Atte Von Wright, University of Eastern Finland, Finland

George Golding, National

Microbiology Laboratory, Canada

*Correspondence:

Florence Crombé, Department of

Bacterial Diseases, Veterinary and Agrochemical Research Centre,

Groeselenberg 99, Brussels 1180, Belgium.

e-mail: flcro@coda-cerva.be

${ }^{\dagger}$ Florence Crombé and M. Angeles Argudín have contributed equally to this work.
From the mid-2000s on, numerous studies have shown that methicillin-resistant Staphylococcus aureus (MRSA), renowned as human pathogen, has a reservoir in pigs and other livestock. In Europe and North America, clonal complex (CC) 398 appears to be the predominant lineage involved. Especially worrisome is its capacity to contaminate humans in close contact with affected animals. Indeed, the typical multi-resistant phenotype of MRSA CC398 and its observed ability of easily acquiring genetic material suggests that MRSA CC398 strains with an increased virulence potential may emerge, for which few therapeutic options would remain. This questions the need to implement interventions to control the presence and spread of MRSA CC398 among pigs. MRSA CC398 shows a high but not fully understood transmission potential in the pig population and is able to persist within that population. Although direct contact is probably the main route for MRSA transmission between pigs, also environmental contamination, the presence of other livestock, the herd size, and farm management are factors that may be involved in the dissemination of MRSA CC398. The current review aims at summarizing the research that has so far been done on the transmission dynamics and risk factors for introduction and persistence of MRSA CC398 in farms.

\section{Keywords: MRSA, ST398, pigs, transmission risk factors, transmission routes, transmission pig models}

\section{INTRODUCTION}

Staphylococcus aureus is a major facultative pathogen, which is associated with a wide spectrum of diseases in both humans and animals (Mandell et al., 2000; Hermans et al., 2010). Ever since antimicrobial therapy was introduced, certain clones of this bacterium have shown the ability to gain resistance against almost all classes of antimicrobial agents to which they are exposed (Lowy, 2003; Malachowa and DeLeo, 2010). Of general concern is resistance to $\beta$-lactamase stable $\beta$-lactam antibiotics in methicillinresistant $S$. aureus (MRSA). The first report on clinical cases of MRSA dates back to 1961, in the United Kingdom (Jevons, 1961). From then on nosocomial MRSA infections emerged, though infrequently, worldwide. In the late 1980s and the early 1990s, MRSA gradually increased in frequency and became a serious pathogen in hospitals throughout the world, the so-called healthcare or hospital-associated MRSA (HA-MRSA) (Enright et al., 2002; Grundmann et al., 2006). Still, in some countries of Europe (i.e., the Netherlands, Finland, Norway, Sweden, and Denmark), HA-MRSA infections have remained sporadic as a consequence of a strict Search and Destroy policy (Deurenberg et al., 2007). In the mid-1990s, a second wave appeared in the epidemiology of MRSA. Cases of MRSA were reported among people without healthcareassociated risk factors, now-called community-acquired MRSA (CA-MRSA) (Udo et al., 1993; Centers for Disease Control, and Prevention (CDC) (1999); Chambers, 2001; Okuma et al., 2002; Kluytmans-VandenBergh and Kluytmans, 2006). From then on, CA-MRSA emerged worldwide and became not only a threat in the community (with a low antimicrobial use) but also, occasionally, in the hospital environment (O’Brien et al., 1999; Saiman et al., 2003). CA-MRSA strains differ from HA-MRSA strains since they have a different accessory genome, carry different staphylococcal cassette chromosome mec (SCCmec) elements, affect different populations, and cause other clinical symptoms (Enright et al., 2002; Graffunder and Venezia, 2002; Grundmann et al., 2002; Okuma et al., 2002; Naimi et al., 2003; Robinson and Enright, 2003; Vandenesch et al., 2003; Ito et al., 2004; Tenover et al., 2006; Wijaya et al., 2006; Tacconelli et al., 2008; Witte, 2009; Yamamoto et al., 2010). Five clonal complexes (CCs), CC5, CC8, CC22, CC 30 , and CC45, were shown to prevail among HA-MRSA isolates while several genetic backgrounds (CC1, CC8, CC30, CC59, CC80, and CC93) were associated to the epidemic spread of CA-MRSA (Enright et al., 2002; Robinson and Enright, 2003; Vandenesch et al., 2003; Deurenberg and Stobberingh, 2009; Witte, 2009; David and Daum, 2010). Presently, however, it becomes ever more difficult to distinguish HA-MRSA from CA-MRSA (Song et al., 2011; Stefani et al., 2012), since clones with a typical hospital-acquired genetic background enter the community and typical clones with communityacquired genetic background enter the hospital (Campanile et al., 2011; Song et al., 2011).

In contrast to humans, antimicrobial susceptibility of $S$. aureus isolates in animals has been initially less continuously documented. The first isolation of MRSA was reported in 1972 from cases of bovine mastitis, with isolates that were believed to be from human origin (Devriese et al., 1972; 
Devriese and Hommez, 1975). Later on, MRSA was found occasionally in animals, mainly in pets and horses (Scott et al., 1988; Cefai et al., 1994; Hartmann et al., 1997; Lee, 2003; Goni et al., 2004). Here too, the strains were mostly human genotypes and accordingly, animals (and mainly companion animals) were perceived as potential vectors for (re-)infection of their human contacts (Scott et al., 1988; Cefai et al., 1994; Manian, 2003). However, in 2005, the first report of a new MRSA clone, in a pig farmer, initiated a third wave in the history of MRSA (Armand-Lefevre et al., 2005). Hereafter, Voss et al. (2005) reported MRSA in a family of pig farmers and their pig that appeared to be resistant to SmaI digestion, and thus not typeable by standard pulsed field gel electrophoresis (PFGE), and belonged to staphylococcal protein A gene ( $s p a)$ type t108. The same MRSA type was isolated in two other cases including a pig farmer and a patient whose father was a veterinarian, which indicated a possible link between pig farming and an increased risk for MRSA carriage (Voss et al., 2005). Indeed, in an additional study, a 760-fold higher MRSA carriage rate among a group of regional pig farmers was found compared to the general Dutch population (Voss et al., 2005). These novel strains were typed using multilocus sequence typing (MLST) as sequence type (ST) 398 and, since the appearing of a ST variant, are generally grouped as CC398 (http://saureus.mlst.net). Since their discovery, livestock, and pigs particularly appeared to be an important reservoir for MRSA CC398 colonization and infection of humans in relation to farming worldwide (Huijsdens et al., 2006; Wulf et al., 2006, 2008a; van Loo et al., 2007; Witte et al., 2007; Khanna et al., 2008; Lewis et al., 2008; Nemati et al., 2008; Denis et al., 2009; Krziwanek et al., 2009; Persoons et al., 2009; Smith et al., 2009; Van den Eede et al., 2009; Mammina et al., 2010; Mulders et al., 2010; Graveland et al., 2011; Vandendriessche et al., 2011a; Crombé et al., 2012a). Moreover, a number of clinical cases caused by MRSA CC398 have been described in animals including pigs (Sergio et al., 2007; van Duijkeren et al., 2007; Schwarz et al., 2008; Meemken et al., 2010; van der Wolf et al., 2012), cows (Feßler et al., 2010; Vanderhaeghen et al., 2010; Holmes and Zadoks, 2011; Spohr et al., 2011), horses (Cuny et al., 2008, 2010; Hermans et al., 2008; Sieber et al., 2011), and dogs (Witte et al., 2007; Floras et al., 2010; Haenni et al., 2012). However, MRSA CC398 is not the only lineage recovered from pigs and other animals. Some types, such as ST9 and ST97, appear to be associated with livestock as well. Yet, MRSA ST398 and ST97 are mainly reported in Europe [European Food Safety Authority (EFSA), 2009; Battisti et al., 2010; GómezSanz et al., 2010; Meemken et al., 2010] and the US (Smyth et al., 2009; O'Brien et al., 2012; Osadebe et al., 2012) while ST9 particularly prevails in Asian countries (Cui et al., 2009; Guardabassi et al., 2009; Neela et al., 2009; Wagenaar et al., 2009). Presently, MRSA strains originating from animals are commonly called livestockassociated MRSA (LA-MRSA). This review focuses on pigs as major reservoir of MRSA and on the possible transmission routes of LA-MRSA on pig herds and farms in general.

\section{OCCURRENCE, DISTRIBUTION, AND HEALTH IMPACT OF LA-MRSA IN PIG HERDS}

Since 2005, numerous publications have appeared focusing on the MRSA occurrence in pigs (Table 1). Most studies reported asymptomatic carriage of MRSA among pigs, in which CC398 appeared as dominant MRSA lineage, particularly in Europe. Currently, MRSA CC398 has been recognized in pigs or on pig farms in 18 European countries [European Food Safety Authority (EFSA), 2009; Huber et al., 2010; Habrun et al., 2011; Overesch et al., 2011], on the American continent in Canada (Khanna et al., 2008), the USA (Smith et al., 2009; Molla et al., 2012; Osadebe et al., 2012; O'Brien et al., 2012) and Peru (Arriola et al., 2011), and also in Asia, including Singapore (Sergio et al., 2007), China (Wagenaar et al., 2009), and Korea (Lim et al., 2012). Furthermore, a wide variety of non-CC398 MRSA types have been identified in pigs or on pig farms (Table 1). In Asia, MRSA CC9 appears as the most prevalent clone associated with pig farming (Sergio et al., 2007; Cui et al., 2009; Guardabassi et al., 2009; Neela et al., 2009; Wagenaar et al., 2009; Larsen et al., 2012; Lo et al., 2012; Tsai et al., 2012; Vestergaard et al., 2012). However, MRSA strains with a "typical" human genetic background (ST5, ST8, ST22, ST30, and ST45) have also been reported in Europe, USA, and Africa, which might indicate transmission of (human) MRSA strains from humans to pigs (Sergio et al., 2007; Khanna et al., 2008; Pomba et al., 2009; Overesch et al., 2011; Fall et al., 2012; Molla et al., 2012; O’Brien et al., 2012).

In 2008, a European baseline study determined the MRSA prevalence in both breeding (i.e., housing and selling breeding pigs) and production holdings (i.e., housing breeding pigs and selling pigs for fattening or slaughtering) from 24 European Union member states and 2 non-member states, based on the analysis of environmental samples [European Food Safety Authority (EFSA), 2009]. Both production types were distinguished since breeding holdings are generally considered to have a better status in terms of management and hygiene practices, health status, and biosecurity measures [European Food Safety Authority (EFSA), 2009; European Food Safety Authority (EFSA), 2010]. The reported MRSA CC398 prevalence varied significantly between countries at breeding holding level, ranging from $0 \%$ in 14 states to $46 \%$ in Spain, and at production holding level, ranging from $0 \%$ in 11 states to $50.2 \%$ in Spain. However, pooling of environmental wipes probably resulted in substantial underestimation of the true prevalence, especially on farms with low in-herd prevalence (Broens et al., 2011a). In the Netherlands, for example, Broens et al. (2011b) reported a MRSA-positive herd prevalence of $67.3 \%$ in breeding holdings and $71.0 \%$ in finishing holdings while in the European baseline study, the herd prevalence was 12.8 and 17.9\%, respectively [European Food Safety Authority (EFSA), 2009]. In addition, farm level rates may increase over time (Broens et al., 2011b; Overesch et al., 2011). Broens et al. (2011b) reported an increase from $\sim 30$ to $75 \%$ over a 2-year timeperiod, probably as a consequence of MRSA transmission between herds.

At animal level the prevalence also differs considerably between countries, ranging from $10 \%$ in Denmark (Guardabassi et al., 2007 ) to $44 \%$ in Belgium (Crombé et al., 2012a). Moreover, agerelated differences in MRSA prevalence were reported (Smith et al., 2009; Broens et al., 2011b; Weese et al., 2011; Crombé et al., 2012a). Piglets have manifestly higher carriage rates compared to sows and fattening pigs (Smith et al., 2009; Broens et al., 2011b; Weese et al., 2011; Crombé et al., 2012a). Also, differences between breeds of pigs have been reported. Indeed, MRSA carriage appeared lower 
Table 1 | Summarized chronology of publications reporting MRSA carriage and infection in pigs and their human contacts, $2005-2012$.

\begin{tabular}{llll}
\hline Year of study & Location & Major finding(s) & Genotype(s) identified ${ }^{\text {a }}$ \\
\hline NS & France & New MRSA clone ST398 in pig farmers. 4.5\% (5/112) pig farmers & ST8, ST5, ST438, and ST398 \\
& & $\begin{array}{l}\text { carried MRSA in the nasopharynx; none of the 27 non-farmers } \\
\text { matched by age, sex, and country of residence carried MRSA. }\end{array}$
\end{tabular}

2004-2005 Netherlands Association between pig farming and high MRSA carriage rates. Three family members (including a 6-month-old girl, patient A) on a pig farm (A) carried identical MRSA strains; another farmer (patient $\mathrm{B}$ ), a veterinarians' son (patient $\mathrm{C}$ ), his father, and his nurse carried the same strain as members of farm $A ; 3.3 \%(1 / 30)$ pigs on farm $A$ had perineal carriage of the same strain; at a meeting of regional pig farmers, 23\% (6/26) were colonized with MRSA in the throat and/or the nose

$2005 \quad$ Netherlands

2005

2005

2005-2006

2006

2006

2004-2007_ Denmark

2007

2007

2007
Singapore

Denmark

Netherlands

Netherlands

Germany

Germany

Clonal spread of MRSA ST398 and transmission between humans and pigs. A woman with MRSA mastitis and her daughter had MRSA nasal colonization; three family members and three co-workers had MRSA throat or nasal carriage; $80 \%(8 / 10)$ pigs had throat, nasal, or perineal carriage

$3.1 \%(2 / 64)$ pigs used in experimental research, $2 \%(1 / 50)$ pigs in a slaughterhouse, and $2 \%$ (1/29) staff workers at an academic hospital's research facilities had nasal MRSA colonization

S. aureus nasal carriage in 10\% (10/100) slaughter pigs; $10 \%$ $(1 / 10)$ were MRSA, and $90 \%$ MSSA

$39 \%(209 / 540)$ pigs in nine slaughterhouses carried MRSA in the nares; transmission of MRSA both prior to arrival and at slaughterhouse was likely

Netherlands Purchase of MRSA-positive pigs as transmission route for MRSA spread. MRSA SSTI in 4 piglets on a breeding farm and 20 pigs on a supplier farm; MRSA nasal carriage in 2 farm workers

Transmission of MRSA ST398 between different kinds of pig farms through purchase of MRSA-positive pigs. 11\% (35/310) pigs on 23\% (7/31) farms had MRSA nasal colonization; 11 MRSA-positive personnel had strains with identical genotype as those of the pigs of their respective farms

Pigs as a source of MRSA CC398. Pigs tested after a person working or living on a pig farm presented with MRSA CC398, spa types t034, t108, or t1793, infection or carriage; $46 \%$ (23/50) pigs on $80 \%(4 / 5)$ farms had nasal carriage of MRSA CC398

Strong association between in-herd prevalence and pig contact intensity. $13 \%$ (85/678) pigs from 18\% (62/347) farms were MRSA-positive; 23\% (20/86) human contacts carried MRSA

Pigs are a reservoir for import of MRSA in hospitals. MRSA was isolated on $70 \%(28 / 40)$ of the farms; no pig colonization rate since nasal samples were pooled

Netherlands Working with pigs is a high risk for acquiring MRSA. 56\% (28/50) farms were MRSA-positive with MRSA detected in pigs or dust samples; $30 \%$ (15/50) farms had one or more MRSA-positive persons
NT by Smal PFGE; spa type t108, t567, or t943

Voss et al. (2005)

ST398/t108; agr type 1; PVL-;TSST-

Huijsdens et al. (2006)

Pig isolates: ST398-V; pig and human isolates: ST22-IV

Sergio et al. (2007)

NT by Smal PFGE; spa types t034 and t1793

ST398-III ${ }^{\mathrm{b}}$, IVa or V/t011, t108, et al. (2007) t1254, t1255, t567, t034, and de Neeling et al. (2007) t943

ST398-IV/t011

van Duijkeren et al. (2007)

ST398-IV or V/t011, t108, t899, van Duijkeren and t1939; PVL-, TSSTet al. (2008)

Pig isolates: CC398/t034

Lewis et al. (2008) ST398 Meemken et al. (2008)

ST398-IV or V/t011, t108, t1451, t2510; PVL-;TSST-

Köck et al. (2009)

NT by Smal PFGE; Pig van den Broek isolates: t011, t108, t567, t899, et al. (2009) t2330; human isolates: t011, t108, t567, t588, t2330, t2741 
Table 1 | Continued

\begin{tabular}{|c|c|c|c|c|}
\hline Year of study & Location & Major finding(s) & Genotype(s) identified ${ }^{a}$ & Reference \\
\hline 2007 & Italy & $\begin{array}{l}\text { A farm worker with clinical symptoms was infected with MRSA } \\
\text { ST398; } 9.1 \%(1 / 11) \text { people living or working on the farm were } \\
\text { MRSA-positive }\end{array}$ & $\begin{array}{l}\text { Patient: ST398-IVa/t899; } \\
\text { Co-worker: spa type t108, } \\
\text { SCCmec type V }\end{array}$ & $\begin{array}{l}\text { Pan et al. } \\
\text { (2009) }\end{array}$ \\
\hline NS & $\begin{array}{l}\text { Ontario, } \\
\text { Canada }\end{array}$ & $\begin{array}{l}\text { MRSA with identical genotype among pigs and humans. } 24.9 \% \\
\text { (71/285) pigs on } 20 \text { farms had MRSA nasal or rectal colonization; } \\
20 \%(5 / 20) \text { pig farmers had MRSA nasal carriage; on five farms } \\
\text { with human colonization, concordant strain types were found in } \\
\text { farmers and pigs }\end{array}$ & $\begin{array}{l}\text { Pig and human isolates: spa } \\
\text { type t034 and NT by Smal } \\
\text { PFGE; pig and human } \\
\text { isolates: USA100-CC5/t002 }\end{array}$ & $\begin{array}{l}\text { Khanna et al. } \\
\text { (2008) }\end{array}$ \\
\hline 2007 & Belgium & $\begin{array}{l}66.3 \% \text { (273/412) pigs were MRSA-positive (nares, skin, per- } \\
\text { ineum, or rectal samples) on } 2 \text { MRSA-positive farms; people } \\
\text { living on one of the two farms had nasal MRSA colonization }\end{array}$ & NT by Smal PFGE & $\begin{array}{l}\text { Dewaele et al. } \\
\text { (2011) }\end{array}$ \\
\hline 2007 & Belgium & $\begin{array}{l}44 \%(663 / 1500) \text { pigs belonging to the } 68 \%(34 / 50) \text { of the farms } \\
\text { sampled carried MRSA. }\end{array}$ & $\begin{array}{l}\text { ST398-IVa or }-\mathrm{V} / \mathrm{t} 011, \mathrm{t} 034 \\
\text { t567, and t2970 }\end{array}$ & $\begin{array}{l}\text { Crombé et al. } \\
\text { (2012a) }\end{array}$ \\
\hline $2003-2008$ & Netherlands & $\begin{array}{l}\text { MRSA from post-mortem samples from pigs. } 16 \%(19 / 116 \text { pigs } \\
\text { with } S \text {. aureus) isolates were MRSA, with MRSA being the first } \\
\text { cause of infection in } 11 \text { pigs }\end{array}$ & $\begin{array}{l}\text { CC398/t011, t108, t367, t899 } \\
\text { and t2330 }\end{array}$ & $\begin{array}{l}\text { van der Wolf } \\
\text { et al. (2012) }\end{array}$ \\
\hline $2007-2008$ & $\begin{array}{l}\text { lowa and } \\
\text { Illinois, USA }\end{array}$ & $\begin{array}{l}\text { Pigs as important reservoir of MRSA ST398. In two farm sys- } \\
\text { tems, } 49 \%(147 / 299) \text { swine and } 45 \% \text { (9/20) farm workers had } \\
\text { MRSA nasal carriage }\end{array}$ & $\begin{array}{l}\text { Pigs and workers isolates: } \\
\text { ST398-V; PVL- }\end{array}$ & $\begin{array}{l}\text { Smith et al. } \\
\text { (2009) }\end{array}$ \\
\hline 2008 & China & $\begin{array}{l}\text { MRSA from Chinese pigs differ from European LA-MRSA clone. } \\
\text { MRSA isolated from dust samples on } 5 / 9(56 \%) \text { pig farms in } \\
\text { Sichuan Province }\end{array}$ & ST9/t899; ST1376/t899; PVL- & $\begin{array}{l}\text { Wagenaar } \\
\text { et al. (2009) }\end{array}$ \\
\hline 2008 & China & $\begin{array}{l}\text { MRSA from Chinese pigs and farm workers differ from European } \\
\text { LA-MRSA clone. MRSA isolates from nares of } 11.4 \%(58 / 509) \\
\text { pigs and } 15 \%(2 / 13) \text { farm workers in four Chinese provinces }\end{array}$ & $\begin{array}{l}\text { ST9/t899; ST912/t899; } \\
\text { ST1297/t899; PVL- }\end{array}$ & $\begin{array}{l}\text { Cui et al. } \\
\text { (2009) }\end{array}$ \\
\hline 2008 & Portugal & $\begin{array}{l}\text { Four pigs and one veterinarian from a pig farm had MRSA nasal } \\
\text { carriage and at a second farm, three pigs had MRSA nasal } \\
\text { carriage }\end{array}$ & $\begin{array}{l}\text { Farm 1: ST398-V/t011, PVL-; } \\
\text { Farm 2: ST30-V/t021, PVL- }\end{array}$ & $\begin{array}{l}\text { Pomba et al. } \\
\text { (2009) }\end{array}$ \\
\hline NS & Malaysia & $\begin{array}{l}\text { Low prevalence of MRSA in pigs. One or more pigs had MRSA } \\
\text { nasal carriage on } 30 \%(9 / 30) \text { of the farms; } 5.5 \%(5 / 90) \text { humans } \\
\text { in contact with pigs had MRSA nasal carriage }\end{array}$ & ST9-V/t4358; ST1-V/t1784 & $\begin{array}{l}\text { Neela et al. } \\
\text { (2009) }\end{array}$ \\
\hline 2008 & Hong-Kong & $\begin{array}{l}16 \%(16 / 100) \text { carcasses on two wet markets had nasal MRSA } \\
\text { colonization. No possibility to access to living pigs }\end{array}$ & ST9-IVb or V/t899 & $\begin{array}{l}\text { Guardabassi } \\
\text { et al. (2009) }\end{array}$ \\
\hline NS & Germany & $\begin{array}{l}\text { Study1: } 70.8 \%(368 / 520) \text { slaughter pigs from } 4 \text { abattoirs; Study } \\
\text { 2: } 49 \%(248 / 506) \text { slaughter pigs from } 1 \text { abattoir had nasal MRSA } \\
\text { colonization }\end{array}$ & ST398-V or $1 I^{\mathrm{b}} / \mathrm{t011}$ and t034 & $\begin{array}{l}\text { Tenhagen et al. } \\
\text { (2009) }\end{array}$ \\
\hline 2008 & Europe & $\begin{array}{l}\text { MRSA ST398 is widely distributed throughout Europe. } 11.7 \% \text { pig } \\
\text { breeding holdings and } 25.5 \% \text { pig production holdings are MRSA } \\
\text { ST398-positive. Results are based on dust samples following the } \\
\text { EFSA guidelines }\end{array}$ & $\begin{array}{l}\text { Dominant clone: ST398/t011; } \\
\text { CC1; CC5; CC8;CC9; ST39 } \\
\text { (CC30); CC97; ST132 } \\
\text { (CC133)/multiple spa types }\end{array}$ & $\begin{array}{l}\text { European } \\
\text { Food Safety } \\
\text { Authority } \\
\text { (EFSA) (2009) }\end{array}$ \\
\hline 2008 & Italy & $\begin{array}{l}\text { Heterogeneity among MRSA in finishing pigs. } 14 \%(98 / 701) \\
\text { pools ( } 10 \text { pigs/pool and } 6 \text { pools/farm) were MRSA-positive on } \\
38 \%(45 / 118) \text { positive holdings }\end{array}$ & $\begin{array}{l}\text { ST398/t011, t034, t108, t899, } \\
\text { t2510, and t2922; ST1/t127; } \\
\text { ST1476/t1730; SCCmec type } \\
\text { V, IVb or 2B + 5d; } \\
\text { ST9-V/t4794; ST97-V/t4795; } \\
\text { ST398-2B + 5d/t4838 }\end{array}$ & $\begin{array}{l}\text { Battisti et al. } \\
\text { (2010) }\end{array}$ \\
\hline
\end{tabular}


Table 1 | Continued

\begin{tabular}{|c|c|c|c|c|}
\hline Year of study & Location & Major finding(s) & Genotype(s) identified ${ }^{a}$ & Reference \\
\hline 2008 & Germany & $\begin{array}{l}52 \%(152 / 290) \text { fattening pig farms are MRSA-positive; with a } \\
\text { prevalence from } 39 \% \text { to } 59 \% \text { from east to south-west of the } \\
\text { country. Results are based on dust samples }\end{array}$ & $\begin{array}{l}\text { CC398-V, Vc, Iva, or NT/t011, } \\
\text { and t034 }\end{array}$ & Alt et al. (2011) \\
\hline 2007-2008 & Spain & $\begin{array}{l}\text { MRSA carriage is lower in Iberian pigs }(28 \%, 30 / 106 ;) \text { than in } \\
\text { Standard White pigs }(83 \%, 130 / 157)\end{array}$ & $\begin{array}{l}\text { ST398/t011, t034; } \\
\text { ST1966/t011, ST1968/t011; } \\
\text { ST1969/t011 }\end{array}$ & $\begin{array}{l}\text { Porrero et al. } \\
\text { (2012) }\end{array}$ \\
\hline 2007-2009 & Ireland & $\begin{array}{l}\text { Absence of MRSA CC398 in pigs and humans. 0\% (0/440) pigs } \\
\text { from } 41 \text { farms had MRSA-positive nasal samples; } 2 \%(2 / 101) \\
\text { human contacts carried (human) MRSA strains }\end{array}$ & ST22; ST1307 & $\begin{array}{l}\text { Horgan et al. } \\
\text { (2011) }\end{array}$ \\
\hline 2008-2009 & Korea & $\begin{array}{l}\text { MRSA clones from both animal and human origin are distributed } \\
\text { among pigs. } 3.2 \% \text { (21/657) pigs carried nasal MRSA on } 22.7 \% \\
(15 / 66) \text { of the farms }\end{array}$ & $\begin{array}{l}\text { ST398/t034; ST541/t034; } \\
\text { ST72/t664, and t2461 }\end{array}$ & $\begin{array}{l}\text { Lim et al. } \\
(2012)\end{array}$ \\
\hline 2008-2009 & Spain & $\begin{array}{l}\text { Pig-to-human transfer of MRSA ST398. MRSA-positive pig } \\
\text { farmer with skin lesion; } 91.7 \%(11 / 12) \text { pigs had nasal MRSA } \\
\text { colonization }\end{array}$ & $\begin{array}{l}\text { Patient and pig isolates: } \\
\text { ST398-IVa or V/t011 and t108; } \\
\text { Patient isolate: ST398-V/t588 }\end{array}$ & $\begin{array}{l}\text { Lozano et al. } \\
\text { (2011a) }\end{array}$ \\
\hline 2008-2009 & USA & $\begin{array}{l}1.3 \%(2 / 157) \text { samples from pigs exhibited at shows were MRSA- } \\
\text { positive }\end{array}$ & $\begin{array}{l}\text { ST398/t3075; ST2136 } \\
\text { (CC9)/t337 }\end{array}$ & $\begin{array}{l}\text { Dressler et al. } \\
\text { (2012) }\end{array}$ \\
\hline 2009-2010 & Switzerland & $\begin{array}{l}\text { Increase of MRSA prevalence within } 2 \text { years among slaughter } \\
\text { pigs. } 2 \%(8 / 405) \text { slaughter pigs had MRSA nasal colonization; } \\
1 \text { year later } 5.9 \%(23 / 392) \text { had MRSA nasal colonization }\end{array}$ & $\begin{array}{l}\text { ST398-V/t034, t011, and } \\
\text { t1451; ST49-V/t208; } \\
\text { ST1-IVc/t2279 }\end{array}$ & $\begin{array}{l}\text { Overesch et al. } \\
\text { (2011) }\end{array}$ \\
\hline 2009 & Denmark & $\begin{array}{l}\text { 74\% (230/311) pigs had MRSA nasal carriage on } 6 \text { MRSA-positive } \\
\text { farms }\end{array}$ & CC398-V/t011 and t034 & $\begin{array}{l}\text { Espinosa- } \\
\text { Gongora et al. } \\
(2011)\end{array}$ \\
\hline 2009 & Switzerland & $\begin{array}{l}1.3 \%(10 / 800) \text { pigs carried nasal MRSA; no MRSA among } 148 \\
\text { pig farmers attending meetings on swine breeding }\end{array}$ & ST398-V/t034 & $\begin{array}{l}\text { Huber et al. } \\
\text { (2010) }\end{array}$ \\
\hline NS & Spain & $\begin{array}{l}\text { Other MRSA lineages than CC398 are able to spread among } \\
\text { pigs. } 20.8 \%(11 / 53) \text { finishing pigs and } 49.1 \%(26 / 53) \text { suckling } \\
\text { pigs coming from two abattoirs (six production chains) had nasal } \\
\text { MRSA colonization }\end{array}$ & $\begin{array}{l}\text { ST398/t011, t108, t1197, and } \\
\text { t2346; ST1379/t3992 (CC97) }\end{array}$ & $\begin{array}{l}\text { Gómez-Sanz } \\
\text { et al. (2010) }\end{array}$ \\
\hline NS & Serbia & $7.1 \%(6 / 84)$ pigs had nasal MRSA colonization & CC45-IVa/t015 & $\begin{array}{l}\text { Velebit et al. } \\
\text { (2010) }\end{array}$ \\
\hline 2009 & Peru & $\begin{array}{l}40 \%(8 / 20) \text { pigs had nasal MRSA carriage originating from } \\
\text { one out of six large-scale holdings; } 5 \%(1 / 20) \text { scavenging pigs } \\
\text { had nasal MRSA carriage originating from } 1 \text { out of } 6 \text { rural } \\
\text { communities }\end{array}$ & $\begin{array}{l}\text { ST398-V/t571; USA300-like } \\
\text { ST8-IVa/t008 }\end{array}$ & $\begin{array}{l}\text { Arriola et al. } \\
(2011)\end{array}$ \\
\hline 2009 & Denmark & $\begin{array}{l}\text { 13\% (101/789) of pigs at slaughter have MRSA, with } 93 \% \text { of } \\
\text { MRSA belonging to CC398, } 4 \% \text { to CC30, and the remaining } \\
\text { to CC1, CC30 isolates carried SCCmec } \mathrm{V}+\text { cadmium zinc resis- } \\
\text { tance gene } c z r C \text {, meaning spread of typical CC398 SCCmec to } \\
\text { other lineages }\end{array}$ & $\begin{array}{l}\text { CC398/t011, t034, t1451, } \\
\text { t2876, t2974; } \\
\text { CC30-V + czrC/t1333; } \\
\text { CC1/t0127 }\end{array}$ & $\begin{array}{l}\text { Agersø et al. } \\
\text { (2012) }\end{array}$ \\
\hline 2009 & Belgium & $\begin{array}{l}\text { In } 26 \text { of } 30 \text { farms (pig and mixed farms), pigs carried MRSA, No } \\
\text { effect of the farm type (pigs only or multispecies) on the MRSA } \\
\text { status of the pigs }\end{array}$ & $\begin{array}{l}\text { ST398-IVa and }-\mathrm{V} / \mathrm{t} 011, \mathrm{t} 034 \\
\text { t567, t571, t1451, t2974, } \\
\text { t3423, and t5943 }\end{array}$ & $\begin{array}{l}\text { Verhegghe } \\
\text { et al. (2012b) }\end{array}$ \\
\hline
\end{tabular}


Table 1 | Continued

\begin{tabular}{|c|c|c|c|c|}
\hline Year of study & Location & Major finding(s) & Genotype(s) identified ${ }^{a}$ & Reference \\
\hline $2009-2011$ & Dakar & $1.3 \%(6 / 464)$ pigs positive for MRSA & ST5-IV/PVL+; ST88-IV & $\begin{array}{l}\text { Fall et al. } \\
(2012)\end{array}$ \\
\hline $2009-2010$ & Spain & $\begin{array}{l}85.7 \% \text { of } 300 \text { pigs analyzed and } 9.3 \% \text { of } 54 \text { pig workers } \\
\text { screened carried CC398 MRSA }\end{array}$ & ST398-IV or V & $\begin{array}{l}\text { Morcillo et al. } \\
\text { (2012) }\end{array}$ \\
\hline 2009-2010 & Netherlands & $\begin{array}{l}3.2 \%(11 / 341) \text { pig slaughterhouse workers, } 47 \% \text { (40/85) gloves } \\
\text { samples, and } 27.5 \%(11 / 40) \text { air samples were MRSA-positive }\end{array}$ & $\begin{array}{l}\text { ST398/t011, t064, t108, and } \\
\text { t2330; ST7/t091; ST8/t064; } \\
\text { ST45/t015 }\end{array}$ & $\begin{array}{l}\text { Gilbert et al. } \\
\text { (2012) }\end{array}$ \\
\hline 2009-2010 & Taiwan & $\begin{array}{l}42.5 \%(127 / 299) \text { pigs from } 11 \text { counties in western Taiwan car- } \\
\text { ried MRSA. } 220 \text { MRSA isolates were recovered from the } 127 \\
\text { positive pigs. } 36 \text { pigs }(28.3 \%, 36 / 127) \text { harbored more than one } \\
\text { MRSA strain }\end{array}$ & $\begin{array}{l}\text { ST9-IV o V/t899 t1939, t2922, } \\
\text { t4132, t4358, and t7616; PVL- }\end{array}$ & Lo et al. (2012) \\
\hline 2010 & Spain & $\begin{array}{l}\text { Pig-to-human transfer of MRSA ST398. MRSA-positive pig } \\
\text { farmer with skin lesion; } 50 \% \text { (9/18) pigs had nasal MRSA }\end{array}$ & ST398-V/t011 and t1451 & $\begin{array}{l}\text { Lozano et al. } \\
\text { (2011b) }\end{array}$ \\
\hline 2010 & $\begin{array}{l}\text { lowa, } \\
\text { Minnesota, } \\
\text { and New } \\
\text { Jersey, USA }\end{array}$ & $\begin{array}{l}58.2 \%(230 / 395) \text { with MSSA and } 6.6 \%(26 / 395) \text { pork samples } \\
\text { with MRSA }\end{array}$ & $\begin{array}{l}\text { 23.1\% MRSA CC398/t011 and } \\
\text { t034; CC5/t002; CC8/t008, } \\
\text { and other spa types (t094, } \\
\text { t078, t273, t803, t2922, } \\
\text { t8314) }\end{array}$ & $\begin{array}{l}\text { O'Brien et al. } \\
\text { (2012) }\end{array}$ \\
\hline 2010 & $\begin{array}{l}\text { Netherlands } \\
\text { and Germany }\end{array}$ & $\begin{array}{l}\text { Absence from pig contact during the summer leave did not } \\
\text { have an impact on MRSA colonization of pig farmers. } 9 \% \text { of } \\
\text { the farmers lost MRSA during summer leave }\end{array}$ & t011, t034, t108, t1451, t1197 & $\begin{array}{l}\text { Köck et al. } \\
\text { (2012) }\end{array}$ \\
\hline 2010 & $\begin{array}{l}\text { Connecticut, } \\
\text { USA }\end{array}$ & $\begin{array}{l}3 \%(8 / 263) \text { pigs and } 22 \%(2 / 9) \text { humans carried MRSA on } 14 \% \\
(5 / 35) \text { farms }\end{array}$ & $\begin{array}{l}\text { 12.5\% (1/8) ST398/t034, } \\
\text { PVL+; 50\% (4/8) MRSA } \\
\text { USA300/t008, PVL+; } 12.5 \% \\
\text { MRSA USA 200/t007, PVL+; } \\
\text { 25\% PFGE NS/t007, PVL- and } \\
\text { PVL+ }\end{array}$ & $\begin{array}{l}\text { Osadebe et al. } \\
\text { (2012) }\end{array}$ \\
\hline 2011 & Thailand & $\begin{array}{l}\text { MRSA-positive in } 15 \% \text { of the } 20 \text { small-scale and none of the } 10 \\
\text { large-scale confined production holdings }\end{array}$ & ST9-IX/t337 & $\begin{array}{l}\text { Larsen et al. } \\
\text { (2012) }\end{array}$ \\
\hline 2011 & Thailand & $4 \%$ (5/126 pig samples) MRSA isolates & ST9/t899 & $\begin{array}{l}\text { Tsai et al. } \\
(2012)\end{array}$ \\
\hline 2011 & Thailand & $\begin{array}{l}50 \%(5 / 10) \text { pork samples and } 40 \%(6 / 15) \text { pig nasal swabs positive } \\
\text { for MRSA }\end{array}$ & $\begin{array}{l}\text { CC9 (ST9, ST2136, } \\
\text { ST2278)-IX/t337 }\end{array}$ & $\begin{array}{l}\text { Vestergaard } \\
\text { et al. (2012) }\end{array}$ \\
\hline NS & Thailand & $10 \%(4 / 40)$ weaning pigs had nasal MRSA colonization & ST9/t337, PVL-, TSST- & $\begin{array}{l}\text { Anukool et al. } \\
\text { (2011) }\end{array}$ \\
\hline NS & Croatia & $\begin{array}{l}\text { 35.3\% (24/68) samples were MRSA-positive obtained from } 8 \\
\text { large pig breeding farms - Results are based on dust samples }\end{array}$ & t011, t108, and t1451 & $\begin{array}{l}\text { Habrun et al. } \\
\text { (2011) }\end{array}$ \\
\hline NS & Denmark & $\begin{array}{l}72.6 \% \text { (284/391) samples with MRSA CC398, including } 230 \\
\text { (74\%) animal and } 54(68 \%) \text { environmental samples (dust sam- } \\
\text { ples) at six Danish-MRSA-positive farms. PFGE analysis revealed } \\
\text { the existence of farm-specific pulsotypes, spread of MRSA } \\
\text { CC398 in Danish pig farms is mainly due to clonal dissemination } \\
\text { of farm-specific lineages }\end{array}$ & ST398-V/t011, t034 & $\begin{array}{l}\text { Espinosa- } \\
\text { Gongora et al. } \\
\text { (2012) }\end{array}$ \\
\hline
\end{tabular}


Table 1 | Continued

\begin{tabular}{|c|c|c|c|c|}
\hline Year of study & Location & Major finding(s) & Genotype(s) identified ${ }^{a}$ & Reference \\
\hline NS & Germany & $\begin{array}{l}\text { Absence of MRSA CC398 in alternative farms. In farms } \\
\text { practising alternative farming different from the intensive } \\
\text { common farming practices, no S. aureus isolates were } \\
\text { obtained from nasal swabs from pigs ( } 178 \text { animals analyzed). } \\
\text { 34.8\% (31/89) nasal human samples were positive for MSSA } \\
\text { not CC398. The only person carrying MRSA CC398 had worked } \\
\text { in an intensive farm }\end{array}$ & $\begin{array}{l}\text { CC1, СC5, СC8, СC9, СC15, } \\
\text { CC25, CC30, СC34, CC45, } \\
\text { CC59, CC97, СC121, СС398, } \\
\text { ST426 }\end{array}$ & $\begin{array}{l}\text { Cuny et al. } \\
\text { (2012) }\end{array}$ \\
\hline NS & Ohio, USA & $\begin{array}{l}3 \%(7 / 240) \text { pigs sampled on farm before marketing, } 11 \% \\
(27 / 240) \text { holding pens at the slaughterhouse, } 2 \%(4 / 235) \text { of } \\
\text { carcasses, and } 4 \%(5 / 135) \text { of retail pork samples were } \\
\text { MRSA-positive }\end{array}$ & $\begin{array}{l}\text { ST398/t034, t539 and t1435; } \\
\text { ST5/t002 and t268; } \\
\text { ST9/t1435; ST39/t123; } \\
\text { ST72/t049; ST1340/t002 }\end{array}$ & $\begin{array}{l}\text { Molla et al. } \\
\text { (2012) }\end{array}$ \\
\hline
\end{tabular}

${ }^{a} S$. aureus strain genotypes are presented in the following format: multilocus sequence type (MLST) or Clonal Complex (CC)-SCCmec type/spa type.

${ }^{b}$ SCCmec type using the method of Zhang et al. (2005).

'SCCmec subtype Vc.

${ }^{d}$ SCCmec type 2B +5 (ccrA2B2-mecB + ccrC) using the method of Kondo et al. (2007).

LA-MRSA, livestock-associated methicillin-resistant S. aureus; MRSA, methicillin-resistant S. aureus; MSSA, methicillin-susceptible S. aureus; NS, Not supplied; NT, not typeable; PFGE, Pulse field Gel Electrophoresis; PVL, presence (+) or absence (-) of the Panton-Valentine leukocidin; SSTI, skin, and soft tissue infection; TSST, presence (+) or absence (-) of the toxic shock syndrome toxin.

in Iberian pigs than in standard white pigs (Porrero et al., 2012). However, this might also be due to differences in rearing methods with Iberian pigs being more outdoors. Hence, caution must be taken when comparing results of between-herd and within-herd prevalence from various studies due to differences in sampling and isolation procedures, number of pigs sampled, sample size and sample populations (finishing vs. breeding pigs, piglets vs. older pigs, open vs. closed farms, pigs at the abattoir vs. pigs at the farm, etc.) (Broens et al., 2011a).

Despite the high MRSA carriage rates, clinical MRSA infections are rarely reported in pigs. MRSA CC398 has been associated with a case of exudative epidermitis in 2006, a condition typically due to Staphylococcus hyicus (van Duijkeren et al., 2007). In addition to skin infections, sporadic reports of infections of the urogenital tract, the uterus, and mammary gland as well as from deep-seated tissues and septicemia have been described (Schwarz et al., 2008; Kadlec et al., 2009; Meemken et al., 2010). Meemken et al. (2010) reported that $43 \%(60 / 138)$ of the S. aureus isolates originating from pathological lesions in pigs, collected over a 4-years period, were identified as MRSA; of these, 95\% (57/60) were MRSA CC398, with the remaining being MRSA CC97. In $35 \%(21 / 60)$ of the cases, MRSA could be considered as primary causative agent for the identified lesion. In another study, S. aureus [including methicillin-susceptible $S$. aureus (MSSA) and MRSA] was only isolated from $\sim 0.6 \%(n=144)$ of the pig samples submitted for post-mortem examination over a 6-years period (van der Wolf et al., 2012). From these S. aureus-positive cases, 116 were included in the study for further investigation. S. aureus was recognized as primary cause of infection in $62 \%(72 / 116)$ of the cases. Of these, $16.3 \%$ (19/116) were MRSA of which 52\% (11/19) assigned MRSA as primary cause of infection. Eighteen strains belonged to CC398 and one to non-CC398 ST1, spa type t127. According to these results, the impact of MRSA on pig health is relatively minor at the moment.

\section{RISK FACTORS FOR INTRODUCTION AND PERSISTENCE OF LA-MRSA IN PIG HERDS}

The European baseline study showed that some factors may be associated with MRSA contamination of breeding holdings, namely herd type, herd size and gilt, and boar replacement policy [European Food Safety Authority (EFSA), 2010]. Accordingly, van Duijkeren et al. (2008) reported that $83.3 \%(5 / 6)$ of the investigated herds, supplying pigs to MRSA-positive herds, were MRSA-positive. Moreover, Broens et al. (2011c) reported an 11fold higher odds ratio for herds, with a MRSA-positive supplier, to be MRSA-positive. Hence, animal trading appears to be an important factor for introduction of MRSA on MRSA-negative herds [van Duijkeren et al., 2008; European Food Safety Authority (EFSA), 2009; Broens et al., 2011c]. Yet, additional risk factors are implicated. Indeed, Broens et al. (2011c) found that 23\% of the herds with a negative supplier and $46 \%$ of farms without supplier were MRSA-positive.

Broens et al. (2011b) conducted a risk factor analysis in the Netherlands and reported, in accordance with the European baseline study, that herd size was highly associated with MRSA prevalence. Larger herds appear more likely to be MRSA-positive compared to smaller herds, due to a higher risk of introduction (between-herd dynamics), a higher number of susceptible animals by birth or purchase, and a higher probability of persistence in larger herds (within-herd dynamics) (Broens et al., 2011b). In this study, however, each individual management variable (i.e., purchase of gilts, hygiene score, and antimicrobial use) was too small to yield a significant effect on the MRSA prevalence but still a significant association was observed between each variable and herd size (Broens et al., 2011b). Consequently, larger herds have a higher probability to be MRSA-positive since multiple risk factors (antimicrobial use, animal trade, and low hygiene level) affecting MRSA prevalence are positively associated with herd size (Broens et al., 2011b). In another risk factor study, performed in Germany, 
herd type, and herd size were shown to play a crucial role in dissemination of MRSA in fattening holdings (Alt et al., 2011). Also regions, type of floor, purchase of pigs, antimicrobial use, and presence of cattle on the farm and animal-flow system were associated with a positive MRSA test result (Alt et al., 2011). However, further research is still necessary to investigate the role of additional factors involved in the dissemination of MRSA on pig farms since MRSA has also been reported on closed farms implementing more stringent biosecurity measures [European Food Safety Authority (EFSA), 2009; Alt et al., 2011]. For example, airborne transmission in areas with a high density of pig farms might be involved in the spread of MRSA between farms given that MRSA has already been reported outside MRSA-positive farms to $150 \mathrm{~m}$ downwind (Schulz et al., 2012). Also, it is clear that the environment plays a role in the transmission of MRSA in farms, since similar CC398 clones have been found among farmers, animals, and environmental samples (Espinosa-Gongora et al., 2012; Pletinckx et al., 2012).

Antimicrobial use is a factor that deserves special attention, as it is an obvious factor suggested to be associated with the emergence and spread of MRSA (Tacconelli et al., 2008; van Duijkeren et al., 2008; Kadlec et al., 2012). However, so far, no straightforward relationship appears from the literature. Broens et al. (2011b,c) reported that batch treatments with antimicrobials resulted in a higher prevalence, though not significant, compared with batches that were not subjected to these treatments. In another longitudinal field study, higher transmission rates were observed when tetracycline and $\beta$-lactams were used (Broens et al., 2012b). In addition, feed supplemented with tetracycline appeared to increase the nasal MRSA CC398 load of piglets in an experimental study (Moodley et al., 2011a). Tetracycline resistance is independent of the SCCmec (Aarestrup et al., 2010), which contains the methicillin resistance gene $(m e c A)$, although the SCCmec cassette type III has a integrated copy of the plasmid pT181 with the tetracycline resistance gene tet $(\mathrm{K})$ (Jensen and Lyon, 2009; Turlej et al., 2011). The use of tetracycline may play a role in the selection and increase of transmission rates of ST398 isolates, since tetracycline resistance genes are present in nearly all ST398 (both MRSA and MSSA) isolates. This broad spread of tetracycline resistance genes has probably been promoted by the use of tetracycline in pig farming, as this antibiotic is one of the most prescribed antibiotics for pigs (Anonymous, 2008; Callens et al., 2012). In fact, only few tetracycline susceptible ST398 strains have been isolated (Davies et al., 2011; Zarfel et al., 2012). But, apart from tetracycline use, the use of other antimicrobial agents could promote the emergence of MRSA CC398. Recently, MRSA ST398 with decreased susceptibility to tiamulin, a pleuromutilin antimicrobial used exclusively in veterinary medicine, has been reported (Kadlec et al., 2010; Rubin et al., 2011). This fact deserves further attention since several genes responsible for pleuromutilin resistance have been found in CC398 isolates (Kadlec and Schwarz, 2009; Kehrenberg et al., 2009; Kadlec et al., 2010; Mendes et al., 2011; Schwendener and Perreten, 2011; Lozano et al., 2012). The first pleuromutilin resistance gene reported in CC398 was $v g a(C)$, which also confers resistance to lincosamides and streptogramin A (Kadlec and Schwarz, 2009). This gene is located on a multiresistance plasmid which carries antimicrobial resistance genes
$\operatorname{aad}(\mathrm{D})$, tet(L), and $d f r(\mathrm{~K})$ as well (Kadlec and Schwarz, 2009). More recently this $v g a(\mathrm{C})$ gene has also been found in a small plasmid (Kadlec et al., 2010). Later on, other $v g a$ genes were reported among CC398 isolates including the $v g a(\mathrm{~A})$ gene carried in different plasmids (Mendes et al., 2011; Lozano et al., 2012), the $v g a(\mathrm{~A})$ variant $v g a(\mathrm{~A}) \mathrm{v}$, and $v g a(\mathrm{E})$, both chromosomal located on different transposons (Schwendener and Perreten, 2011; Lozano et al., 2012). An additional pleuromutilin resistance gene found among CC398 is the gene $c f r$, which also confers resistance to phenicols, streptogramin A and oxazolidinones (Kehrenberg et al., 2009). The $c f r$ gene is located on plasmids and is transferable within and between staphylococcal species. Also, it was first detected in a plasmid from a bovine Staphylococcus sciuri strain (Kadlec et al., 2012). Especially worrisome is that this multiresistance gene has also been found in other gram-positive and gram-negative bacteria (Kadlec et al., 2012). Although these data suggest that various antimicrobial agents play a role in the ST398 transmission, there are some studies that report high transmission rates without the use of antimicrobial treatment. Indeed, Crombé et al. (2012b) have shown an extremely efficient transmission of MRSA CC398 between pigs without any antimicrobial treatment. It has even been shown that MRSA can be present in pigs with no antimicrobial use at all (Weese et al., 2011). On the other hand, in alternative pig farming systems, where no preventive antimicrobial treatment is used, absence of MRSA was reported (Cuny et al., 2012). Nevertheless, such loose data are difficult to interpret since more factors differ between these organic farms and conventional pig farms. The alternative farming, as studied by Cuny et al. (2012), in contrast to conventional fattening methods implies smaller farms with straw bedding and low animal density. Interestingly, in this study, one farm worker, who previously worked in a conventional pig farm, carried MRSA CC398 (Cuny et al., 2012). Consequently, it seems that antimicrobial use is not requested for MRSA acquisition and transmission among pigs but it is likely to have some influence on the MRSA load and/or to predispose animals to MRSA colonization, which might result in an increased prevalence at farm level.

Besides antimicrobials, heavy metals such as copper have been shown to promote co-selection of antimicrobial resistance and probably the spread of antibiotic resistant bacteria (Hasman et al., 2006). In fact, zinc-oxide appeared to increase the nasal MRSA CC398 load of piglets (Moodley et al., 2011a). Zinc is commonly used in pig feed, at 50-125 ppm, as it plays an important role in various physiological processes (Katouli et al., 1999; Hill et al., 2000). Moreover, zinc fed at high dietary levels (2000-3000 ppm) is widely used in the early phases of the nursery period since it reduces the incidence of diarrhea and increases weight gain in newly weaned pigs (Jacela et al., 2010). Hence, it has been hypothesized that the emergence of MRSA ST398 in pigs is also driven by the use of zinc-oxide (de Neeling et al., 2007; van Duijkeren et al., 2008; Aarestrup et al., 2010; Cavaco et al., 2011). Zinc-oxide has the potential to co-select specifically for MRSA ST398 since $c z r C$, which encodes for cadmium and zinc resistance, is present within the SCCmec cassette type V element in ST398 (Cavaco et al., 2010). Notify, however, that a substantial proportion of MRSA ST398 strains, as those that carry the SCCmec cassette type IV, are susceptible to zinc indicating that zinc resistance is 
not the only factor contributing to the spread of MRSA (Cavaco et al., 2011). Actually, similarly to tetracycline treatment, it has been reported that transmission of MRSA between positive and negative animals was not influenced by the short-term exposure to zinc-oxide (Moodley et al., 2011a). Interestingly, other metal resistance genes have been discovered recently in novel SCCmec cassette types IX and X among MRSA CC398 isolates recovered from participants at a veterinary conference in Denmark (Li et al., 2011). The SCCmec cassette type IX was found in an isolate from a Thai participant, while the SCCmec cassette type X was described in an isolate from a Canadian. Both SCCmec cassettes include copper ( $c o p B$ gene), cadmium ( $c a d D X$ operon), and arsenate ( $\operatorname{ars} R B C$ or arsDARBC operons) resistance elements (Li et al., 2011). So far, however, few studies determined susceptibility to copper sulfate in MRSA CC398 isolates from pig origin (Cavaco et al., 2011). Moreover, Cavaco et al. (2011) reported no association between the minimal inhibitory concentrations (MICs) of copper sulfate and methicillin resistance. Both MRSA (20\%) and MSSA (66\%) isolates showed high levels of resistance to copper sulfate (MIC > $12 \mathrm{mM}$ ) (Cavaco et al., 2011). Still, copper sulfate resistance has been described in other gram-positive livestockassociated bacteria (i.e. enterococci) (Aarestrup and Hasman, 2004). Given the few reports, further research should be done to establish the prevalence of metal resistance genes other than $c z r C$ among LA-MRSA as well as the possible role of these metals in its dissemination among pigs.

\section{TRANSMISSION OF LA-MRSA \\ TRANSMISSION FROM PIGS TO PIGS}

Transmission between hosts is a critical feature in the epidemiology of any pathogen (Massey et al., 2006). Since pigs have been recognized as important reservoir of LA-MRSA, studies have been done to determine the within- and between-herd transmission routes. From these studies it appeared that MRSA can be transmitted among pigs by direct and indirect contact (Figure 1).

\section{Direct transmission}

Transmission by direct contact is probably the main route for MRSA transmission between pigs (Broens et al., 2012a,b). Indeed, it has been suggested that MRSA-positive pigs might play a crucial role in transmission of these bacteria to negative animals (horizontal transmission) (Broens et al., 2011c,d). In that way, only a few positive animals can result in propagation of MRSA on farms or even beyond farms, through purchase of MRSA-positive pigs (van Duijkeren et al., 2008; Espinosa-Gongora et al., 2012). Additionally, some studies suggested MRSA transmission between pigs in slaughterhouses due to the high density of the animals during the housing in the abattoir (de Neeling et al., 2007; Tenhagen et al., 2009; Broens et al., 2011d). Broens et al. (2011d) reported that MRSA-negative pigs became MRSA-positive within a short time during transport to the abattoir, going from 0 to $10.3 \%(12 / 117)$, and at stunning, 59.8\% (70/117) of these animals were positive. Nevertheless, transmission by indirect contact appeared to play an additional role since $43.3 \%$ of the negative animals from a single batch were positive at stunning, even without contact with other batches.

MRSA can also be transmitted from sows to their offspring (vertical perinatal transmission) (Espinosa-Gongora et al., 2011; Weese et al., 2011; Broens et al., 2012a; Verhegghe et al., 2012a). In fact, in an experimental study, transmission of MRSA from a sow to all newborn piglets has been demonstrated, representing the effectiveness of vertical perinatal transmission (Moodley et al., 2011b). On top of this, some studies (Weese et al., 2011; Verhegghe et al., 2012a) reported that piglets from MRSA-positive sows were more likely to be MRSA-positive. Still, MRSA was also reported in piglets from negative sows, indicating that other factors might additionally be involved. In this context, Verhegghe et al. (2012a) recently reported differences in MRSA colonization trends between different farrow-to-finish farms (i.e., low colonization vs. high colonization farms). In this study, each farm could be considered as a closed system in which different factors (such as environmental contamination) might play a role in the
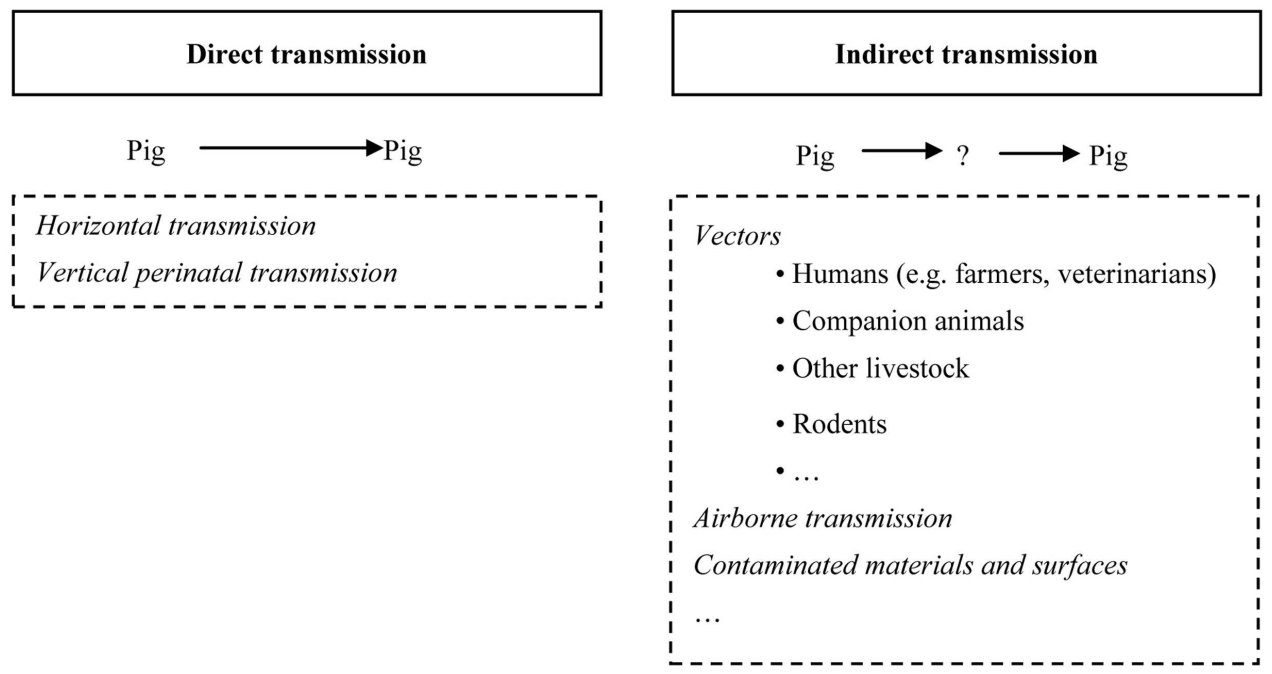

FIGURE 1 | Schematic overview of the potential transmission routes of MRSA between pigs. 
colonization of animals. Moreover, piglets either appeared to be intermittent carriers or were recolonized over time. Consequently, the sow's colonization status is important and should be considered when implementing control measures. However, differences in colonization percentages between farms complicate the standardization of hygienic measures and require well-adapted control measures on each farm.

\section{Indirect transmission}

Humans have been shown to be susceptible to colonization/contamination with LA-MRSA (see next section), therefore, it is likely that persons in contact with pigs act as vectors, transmitting MRSA while handling the animals (within-herd dynamics) or introducing MRSA in negative farms in the case of veterinarians (between-herd dynamics).

Companion animals (cats and dogs) are commonly recognized as sources and vectors for recurrent MRSA colonization or infection of their human contacts (Manian, 2003; Sing et al., 2008; Denis et al., 2009; Loeffler and Lloyd, 2010). Generally, MRSA strains isolated from these animals have a human genetic background. However, LA-MRSA CC398 has occasionally been detected in cats and dogs due to transmission from humans (mainly veterinary personnel) (Witte et al., 2007; Nienhoff et al., 2009; Floras et al., 2010; Haenni et al., 2012). Until now, the prevalence of MRSA CC398 in companion animals residing on farms is unknown. Yet, Denis et al. (2009) reported positive MRSA carriage in dogs living in pigs farms. Moreover, Pletinckx et al. (2012) reported that cats and dogs living on a LA-MRSA-positive pig farm carried MRSA isolates related to those of the pigs living on the farm. Accordingly, companion animals residing on the farm may act as vectors, transporting MRSA from one area of the farm to another (withinherd dynamics) (Pletinckx et al., 2012). It was also remarkable that other "domesticated" animals (e.g., goats) residing on the farm appeared to carry related MRSA strains, even without direct contact with pigs (Pletinckx et al., 2012). So far, the role of other farm animals (e.g., poultry, cattle, and horses), on mixed farms, as a source of MRSA carriage in pigs remains largely unknown. Poultry and cattle appear to carry MRSA, though with a lower prevalence compared to pigs residing on the farm, and might therefore also play a role in the dissemination of MRSA on the farm (Pletinckx et al., 2011, 2012; Verhegghe et al., 2012b). Presently, few studies investigated the MRSA CC398 carriage rates in poultry (Nemati et al., 2008; Persoons et al., 2009; Mulders et al., 2010; Monecke et al., 2013). In Belgium, 12\% (10/81) of S. aureus isolates from healthy chickens on 5 out of 39 sampled farms were found to be MRSA CC398 (Nemati et al., 2008). In another study, Persoons et al. (2009) reported a MRSA CC398 carriage rate of 10.7\% (8/75) within $14.3 \%(2 / 14)$ of the investigated broiler farms. Moreover, MRSA CC398 was not detected in laying hens (Persoons et al., 2009). Similarly, in the Netherlands, MRSA CC398 was detected among 6.9\% (28/405) broilers originating from 40 Dutch slaughter flocks of which 35\% were positive (Mulders et al., 2010). Though MRSA CC398 has been found in poultry isolates, the majority of isolates reported, in both diseased and healthy chickens, belonged to the CC5 (Monecke et al., 2013), which is also one of the most successful human-associated lineages (Lowder et al., 2009). Concerning horses, MRSA CC398 has mainly been reported in equine clinics (Cuny et al., 2008; Hermans et al., 2008; Van den Eede et al., 2009; Sieber et al., 2011) but limited data is available at farm level (Van den Eede et al., 2012, 2013). In West-European horses admitted to a Belgian veterinary clinic, a MRSA CC398 carriage rate of 10.9\% (12/110) was found (Van den Eede et al., 2009). However, Van den Eede et al. (2012) recently reported a low prevalence $(0.53 \%)$ at farm level in Belgium. Similarly, very low and even absent farm level carriage rates of MRSA CC398 have been reported in the Netherlands (Busscher et al., 2006), Slovenia (Vengust et al., 2006), and Atlantic Canada (Burton et al., 2008). Healthy carriage of MRSA CC398 has also occasionally been reported in bovines. Carriage rates among veal calves have been reported ranging from 1\% in Switzerland (Huber et al., 2010), 6.5\% in France (Haenni et al., 2011) to $28-50 \%$ in the Netherlands (Mooij et al., 2007; Graveland et al., 2009, 2010). In Germany, MRSA CC398 was detected in nasal samples of dairy cows and calves on a farm where also pigs were raised and where MRSA was also found in mastitis milk samples (Spohr et al., 2011). Also in mastitis, MRSA CC398 has been reported in Switzerland (Huber et al., 2010; Sakwinska et al., 2011), Germany (Monecke et al., 2007; Feßler et al., 2010), and Belgium (Vanderhaeghen et al., 2010). In Switzerland, MRSA CC398 accounted for $1.4 \%(2 / 142)$ of the S. aureus strains from mastitis milk samples (Huber et al., 2010). In Germany, withinherd prevalences of MRSA CC398-positive cows were found to vary between 1.4 and $16.7 \%$ in three dairy farms (Spohr et al., 2011). In Belgium, a high prevalence of MRSA cases of subclinical and clinical mastitis in cows has been reported (Vanderhaeghen et al., 2010). Particularly, mastitis caused by MRSA CC398 was detected in $10 \%$ of tested Belgian farms (Vanderhaeghen et al., 2010).

Rodents are recognized for their role in transmission and persistence of zoonotic bacteria on livestock farms (Meerburg et al., 2006). van de Giessen et al. (2009) reported MRSA CC398 for the first time in black rats (Rattus rattus) living on pig farms. Later on, Pletinckx et al. (2012) demonstrated that 70.6\% (12/17) of the black rats (Rattus rattus) and voles (Microtus arvalis) caught on four MRSA-positive farms carried MRSA CC398. Obviously, rodents may easily be contaminated by direct contact with contaminated feces, dust or by inhalation when roaming around in MRSA-positive stables. From then on, they can transport MRSA to other pig units (within-herd dynamics) or even beyond farms (between-herd dynamics).

As mentioned previously, the role of the environment in the spread of MRSA might be underestimated. Several studies reported MRSA-positive environments in association with MRSApositive pigs [European Food Safety Authority (EFSA), 2009; van den Broek et al., 2009; Espinosa-Gongora et al., 2012; Friese et al., 2012; Pletinckx et al., 2012; Verhegghe et al., 2012a]. Furthermore, though cleaning and disinfection procedures are used, MRSA might survive in the environment and remain a source of contamination for newly introduced negative animals (Broens et al., 2011d). Moreover, LA-MRSA might be introduced by contaminated feed or material entering the pig units (Amass et al., 2006).

Finally, MRSA has been reported in air samples on several pig farms (Dewaele et al., 2011; Friese et al., 2012; Pletinckx et al., 2012; Verhegghe et al., 2012a). Apart of direct contact, 
airborne transmission is also a possible transmission route of MRSA between humans as has been reported in hospitals (Eames et al., 2009). Therefore, it is likely to occur between pigs within a farm. Moreover, airborne transmission might play a role in dissemination of MRSA between herds in close proximity to each other. Antimicrobial resistant $S$. aureus has been recovered outside pig facilities to at least $150 \mathrm{~m}$ downwind (Gibbs et al., 2006; Schulz et al., 2012). At present, however, the relative contribution of indirect transmission routes needs further investigation.

\section{TRANSMISSION FROM PIGS TO HUMANS}

Numerous studies reported that persons living or working on pig farms, including farmers and their family members, veterinarians, and slaughterhouse workers, are at increased risk for being colonized or infected with LA-MRSA (Voss et al., 2005; Lewis et al., 2008; van Duijkeren et al., 2008; Denis et al., 2009; van den Broek et al., 2009; Huber et al., 2010; Mulders et al., 2010; van Cleef et al., 2010a,b; Bisdorff et al., 2011; Garcia-Graells et al., 2012). In Belgium, 37.8\% (48/127) persons working or living on 25 out of the 49 farms investigated carried MRSA CC398 (Denis et al., 2009). Another study reported that 9.5\% (14/146) of the Belgian veterinarians who participated in this survey carried MRSA, of which 7.5\% (11/146) belonged to MRSA CC398 (Garcia-Graells et al., 2012). Moreover, van Cleef et al. (2010a) reported that $5.6 \%(14 / 249)$ of the slaughterhouse workers enrolled in this study were MRSA-positive, which is significantly higher than the general prevalence in the Netherlands (0.1\%) (Wertheim et al., 2004). Though exact transmission routes between pigs and humans have not been elucidated yet, it is likely that, similarly to pigto-pig transmission, it occurs by direct and indirect contact (i.e., transmission by contaminated air or/and environment). Moreover, the presence of MRSA in humans is likely to be associated with the intensity of animal contact and with the within-herd MRSA prevalence (Meemken et al., 2008; Graveland et al., 2010). Graveland et al. (2011) reported that the MRSA prevalence in veal calf farmers and their family members decreased from 26 to $11 \%$ in absence of animal-exposure (-58\%), with only $7 \%(11 / 155)$ of persistent carriers, suggesting that MRSA CC398 is a poor persistent colonizer in most humans. In addition, van Cleef et al. (2012) reported that, after short occupational exposure to MRSA-positive pigs or veal calves, MRSA was detected among 17\% (34/199) of the field workers but within $24 \mathrm{~h} 94 \%$ (31/34) was again free of MRSA while the others became negative shortly thereafter. In contrast, Köck et al. (2012) reported that 59\% (16/27) of previous MRSA-positive farmers did not clear their MRSA during summer leave, concluding that the absence from pig contact during the summer leave did not have an impact on MRSA colonization of pig farmers. Therefore, further studies are necessary to determine the capacities of LA-MRSA CC398 to persistently colonize humans.

\section{TRANSMISSION BETWEEN HUMANS}

Presently, LA-MRSA has infrequently been reported beyond animal-exposed communities (van Loo et al., 2007; Cuny et al., 2009; Golding et al., 2010; van Cleef et al., 2010b, 2011; Wulf et al., 2012). Some studies examined human-to-human transmission of MRSA CC398 in hospital settings. Based on observational data, Wassenberg et al. (2011) reported that the relative nosocomial transmission risk for MRSA ST398 was 0.28 compared to non-MRSA ST398 genotypes. In an additional study, it appeared that MRSA ST398 was six times less transmissible compared to non-MRSA ST398 genotypes in Dutch hospitals (Bootsma et al., 2011). Moreover, recent genome sequencing data has suggested that the CC398 lineage originated from humans and later spread to livestock, and that this jump from human to animals was followed by a decreased capacity of human colonization, transmission, and virulence (Price et al., 2012). Still, the need to evaluate the transmission risk outside the hospital setting (i.e., in the healthy community) remains.

As for pigs, LA-MRSA ST398 does not appear to be highly infectious for humans, although reports on skin infections with MRSA have occasionally been published (Yao et al., 2010), as well as reports on more serious infections such as deep abscesses, cellulites, necrotizing fasciitis (Pan et al., 2009; Soavi et al., 2010), bacteremia (van Belkum et al., 2008; van der Mee-Marquet et al., 2011), and endocarditis (Ekkelenkamp et al., 2006). However, these data have to be interpreted with caution due to the over interest in such infections. During a wide EU surveillance, Grundmann et al. (2010) could not find any MRSA ST398, but a low prevalence of MSSA ST398 was found. So, infections with MRSA ST398 seem to be rare, but one should remain vigilant.

Albeit the increase in MRSA prevalence among (animalexposed) humans, hospital outbreaks caused by LA-MRSA have only been occasionally reported so far (Witte et al., 2007; van Rijen et al., 2008, 2009; Wulf et al., 2008b; Pan et al., 2009; Schijffelen et al., 2010). In a Dutch hospital, van Rijen et al. (2008) reported that $13 \%(3 / 23)$ of the patients with MRSA not typeable by PFGE had an active infection caused by MRSA compared to $42 \%(21 / 50)$ of the patients with MRSA typeable by PFGE, suggesting a lower virulence of LA-MRSA. This is in accordance with the fact that, up till now, few virulence determinants have been detected among LA-MRSA CC398 (van Belkum et al., 2008; Welinder-Olsson et al., 2008; Yu et al., 2008; Kadlec et al., 2009; Walther et al., 2009; Salmenlinna et al., 2010; Schijffelen et al., 2010; Stegger et al., 2010; Argudín et al., 2011; Hallin et al., 2011; Monecke et al., 2011). However, a continuous surveillance of its epidemiology and virulence determinants is warranted, since some CC398 isolates with important human virulence factors as the bicomponent Panton-Valentine leukocidin (van Belkum et al., 2008; WelinderOlsson et al., 2008; Yu et al., 2008; Salmenlinna et al., 2010; Stegger et al., 2010) or staphylococcal enterotoxins (Kadlec et al., 2009; Argudín et al., 2011) have been reported. Moreover, livestockassociated CC398 has been linked to an increase in MRSA infection in northern Europe (van Cleef et al., 2011).

\section{PIG MODELS TO STUDY COLONIZATION AND TRANSMISSION DYNAMICS}

At present, a number of experimental colonization models have been developed in order to understand colonization and transmission dynamics of LA-MRSA among pigs, with the aim of future use for development of intervention strategies (Table 2) (Moodley et al., 2011b; Broens et al., 2012a; Crombé et al., 2012b; 


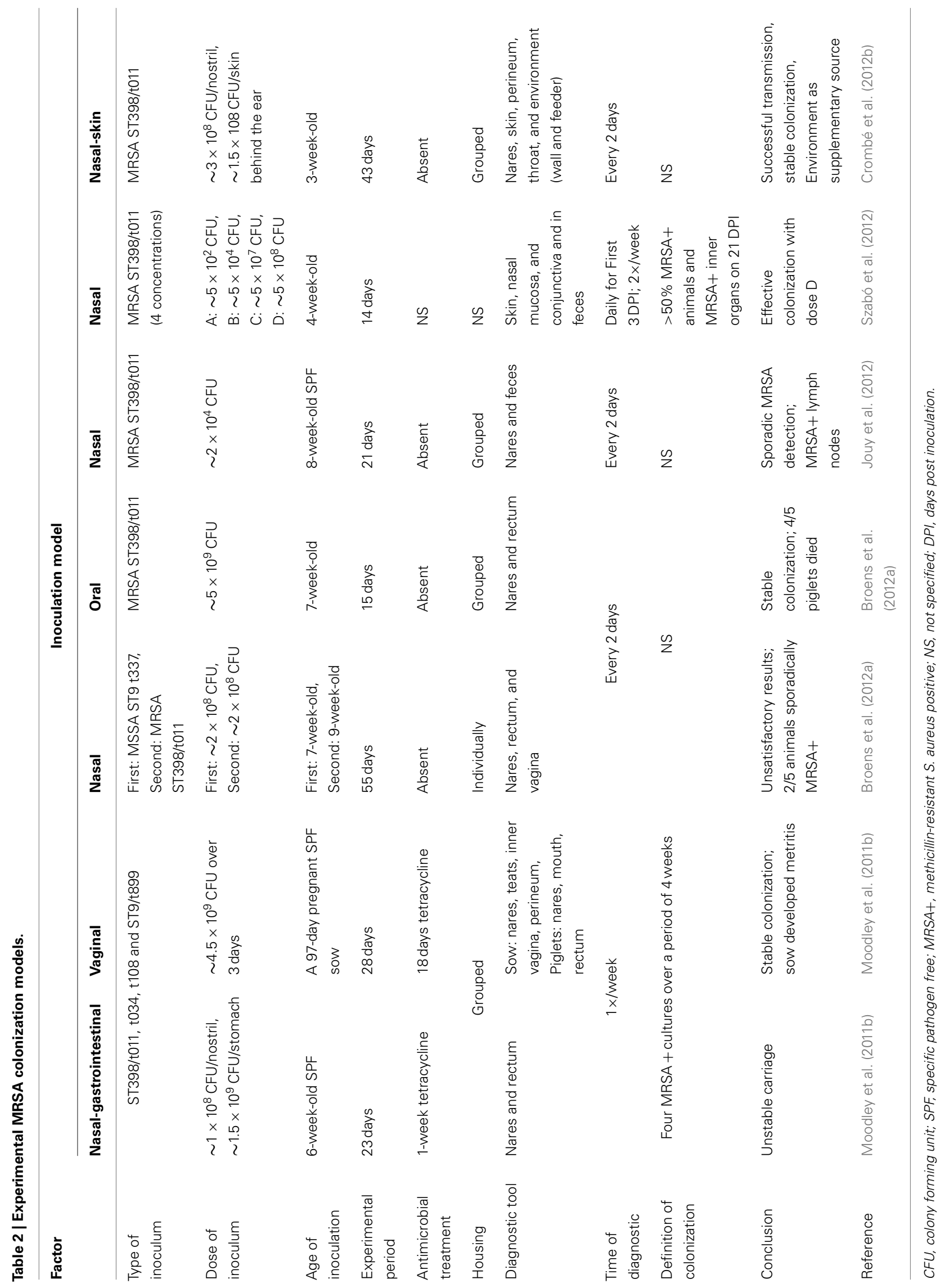


Jouy et al., 2012; Szabó et al., 2012). The experimental design (i.e., inoculation strategy, type and dose of inoculum, age of the animals, strain, and use of antibiotics), the laboratory techniques as well as the pre-defined criteria for colonization of these models differ largely which makes comparison difficult.

Nasal and nasal-gastrointestinal inoculation with LA-MRSA has been found not to result in successful colonization of piglets in some studies (Moodley et al., 2011b; Broens et al., 2012a), while others achieved colonization using relatively high bacterial inoculum doses (Broens et al., 2012a; Crombé et al., 2012b; Szabó et al., 2012). Unfortunately, in the study of Broens et al. (2012a), this high dose led to the development of lethal necrotizing pneumonia in $80 \%(4 / 5)$ of the inoculated animals, making this procedure unsuitable for future experiments. In contrast, Szabó et al. (2012) reported colonization without any clinical implications though MRSA was detected in the inner organs (i.e., palatine tonsils, mandibular lymph nodes, spleen, lung, and ileocecal lymph nodes), 21 days after inoculation (Szabó et al., 2012). Interestingly in this context is that even if a low bacterial inoculum dose does not result in effective colonization, MRSA can be detected in the tonsils and the lymph nodes draining the neck (i.e., axillary, retropharyngeal, and cervical lymph nodes) (Jouy et al., 2012). It remains however unclear why high inoculum doses are needed to get individual animals colonized. It may be hypothesized that in vitro culture does not create the best physiological state of the bacterium, while this is the case when the bacteria underwent an animal passage.

Moodley et al. (2011b) described an intra-vaginal inoculation method which, in contrast to their first nasal-gastrointestinal model, was successful and resulted in stable colonization of the sow and her piglets after farrowing. However, from a practical point of view, this vaginal inoculation model is not evident due to the timeconsuming aspect and the health risk of the method, illustrated by the development of lethal metritis in one of the sows. Consequently, these experimental colonization studies pointed out the complexity of colonization with LA-MRSA. Both host-associated and environmental factors could influence this inherent variation in susceptibility to MRSA carriage (Moodley et al., 2011b; Broens et al., 2012a; Crombé et al., 2012b; Szabó et al., 2012).

Using these experimental colonization models, transmission experiments were performed by our team (Crombé et al., 2012b) and the team of Broens et al. (2012a) to quantify the spread of MRSA among weaned piglets. In our study, shortly after introduction of MRSA ST398, transmission occurred, indicating a very rapid spread (Crombé et al., 2012b). Another observation is that, depending on the animal, carriage may be intermittent, suggesting that animals recover without immunity and thus become susceptible again. Therefore, to assess the transmission rate of MRSA among weaned piglets, transmission was assumed to be in accordance with a susceptible-infectious-susceptible (SIS) model (Velthuis et al., 2003). The basic reproduction ratio $\left(R_{0}\right)$, which characterizes transmission, estimated based upon these experiments varied between 3.92 and 52.54. If the $R_{0}$ is above 1 , it means that a typical infectious animal generates more than one secondary case and that the agent is likely to persist in the population (Velthuis et al., 2003, 2007). Our observations are in accordance with the other recent study of Broens et al. (2012a) whom also investigated the transmission potential of MRSA ST398 though with different methodologies. Broens et al. (2012a) reported a $R_{0}$ that varied between 3.7 and 4.3 . The results obtained in these studies therefore suggest that, after introduction, MRSA ST398 can easily spread among animals (despite the absence of antimicrobial usage), with a tendency to become established.

\section{CONTROL MEASURES}

As presented in Figure 2, various prevention and intervention strategies have currently been suggested. Yet, the question remains open whether strict and extensive (sometimes costly and laborious) biosecurity procedures should be implemented for MRSA control knowing that, for now, the clinical relevance of MRSA CC398 remains minor (Meemken et al., 2010; van der Wolf et al., 2012). Also, if implemented, the effectiveness of the measures still needs to be certified since common measures such as washing (spraying with water, soaping, and rinsing with water) are not likely to affect the presence of MRSA on the skin of sows in MRSA-positive farms (Verhegghe et al., 2011).

It has been stated that reducing the antimicrobial use could reduce the number of colonized animals and/or lower the MRSA load shed by these animals (Broens et al., 2012b). Indeed, as mentioned previously, Broens et al. (2012b) recently reported higher transmission rates when tetracycline and $\beta$-lactams were used. Furthermore, Moodley et al. (2011a) showed that feed supplemented with tetracycline appeared to increase the nasal MRSA CC398 load of piglets in an experimental study but without influencing the transmission of MRSA to MRSA-negative animals. These findings might be explained by a selective advantage of MRSA CC398 compared to susceptible strains in the presence of these antimicrobials. However, several studies reported MRSA transmission even in absence of antimicrobial use (Weese et al., 2011; Broens et al., 2012a; Crombé et al., 2012b). So, antimicrobial use might have some influence on the MRSA load and/or predispose animals to MRSA colonization but it does not appear to be essential for MRSA acquisition and transmission. This suggests that reducing antimicrobial usage alone will not be sufficient to eradicate MRSA from a pig herd.

In light of MRSA CC398 control measures, it has been suggested that a $S$. aureus vaccine might help to reduce the number of colonized animals by inducing immunity and thus preventing colonization (Fluit, 2012). In murine animal models, antibodies directed against microbial surface components recognizing adhesive matrix molecules, immune-modulating proteins, and toxins were found to protect against nasal colonization and infection (Holtfreter et al., 2010). However, in humans, doubts on the feasibility of effective immunization against $S$. aureus have already been raised. Indeed, none of the anti-staphylococcal vaccines have successfully passed clinical trials up to now (Verkaik et al., 2011). Besides, it was found that colonization with $S$. aureus elicited a significant antibody response in persistent carriers compared to non-carriers or intermittent carriers, however, this does not seem sufficient to eliminate S. aureus (van Belkum et al., 2009; Verkaik et al., 2009). Moreover, S. aureus carriers still appeared to be susceptible to $S$. aureus infection despite the presence of high 


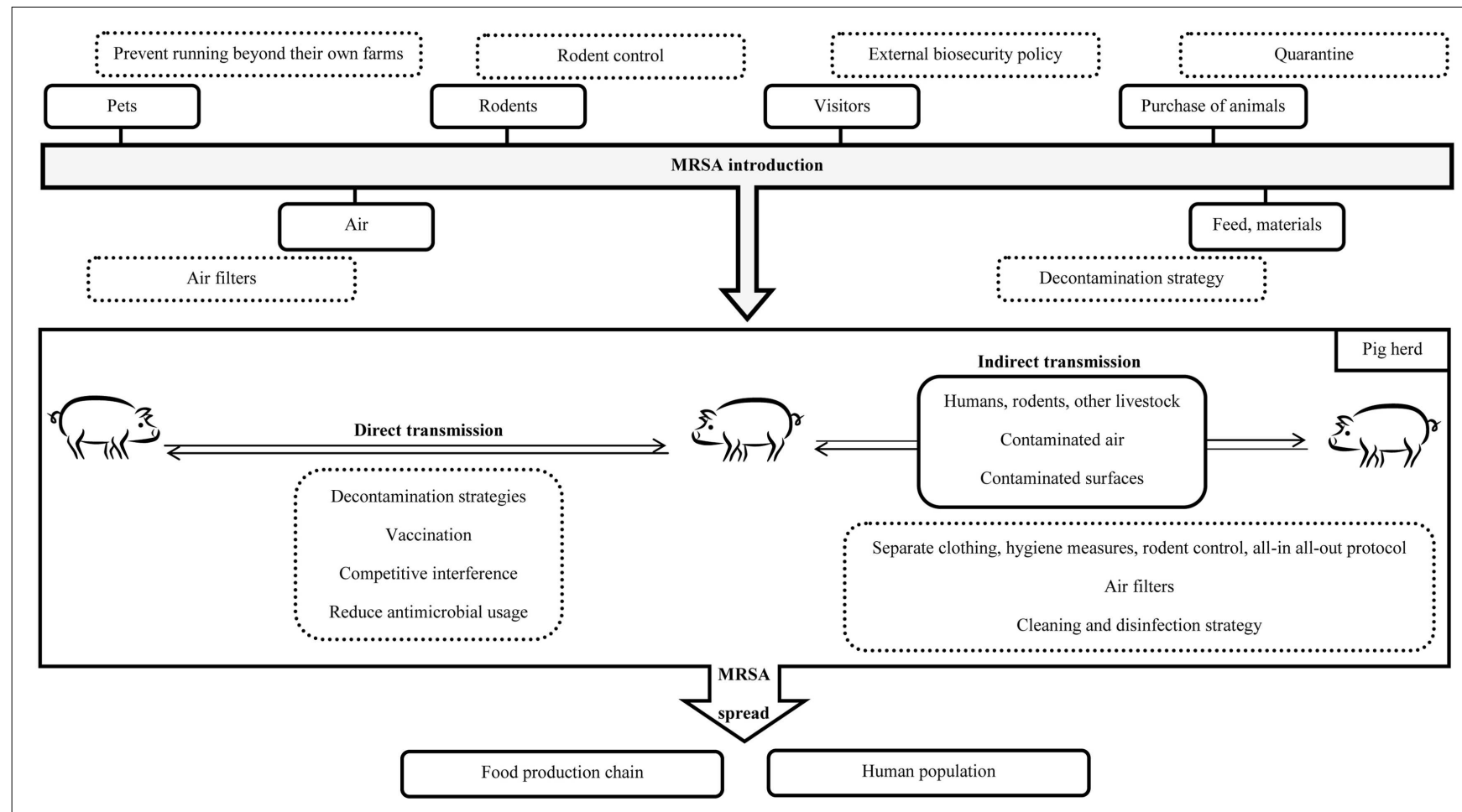

FIGURE 2 | Schematic representation of possible MRSA transmission routes (black line) and theoretical intervention strategies (pointed gray).

anti-staphylococcal antibodies. In fact, it is known that S. aureus carriers have a higher risk for developing infections compared to non-carriers (Wertheim et al., 2005). As in humans, it might be hard to induce immunity to $S$. aureus (mainly LA-MRSA) in pigs by vaccination knowing that, as mentioned previously, LAMRSA does typically not induce disease. Actually, a recent study (Crombé et al., 2013) reported that a LA-MRSA isolate (ST398, spa type t011, SCCmec type V) did not elicit a significant humoral immune response in recently weaned, conventionally raised pigs, suggesting a low immunogenic potential of this strain in this age group during colonization. The asymptomatic carriage of this isolate induced an increase of immunoglobulin (Ig) G levels directed against staphylococcal microbial surface components recognizing adhesive matrix molecules (MSCRAMMs), which are known to play a role in S. aureus colonization. In contrast, IgG levels directed against staphylococcal toxins or immune-modulating proteins decreased over time, suggesting absence of bacterial invasion (Crombé et al., 2013).

Since the humoral immune response alone appears to be inadequate to eliminate $S$. aureus in humans, the role of the cellular immune response in protection against $S$. aureus needs to be considered. Recently, Arlian and Tinker (2011) developed a vaccine that combines a $S$. aureus antigen and an adjuvant, respectively IsdA (which is important in S. aureus colonization) and cholera toxin (CT) A2/B (a potent immunostimulatory molecule that binds to and targets effector cells to the mucosal site). Intranasal administration of this IsdA-CTA2/B chimera in mice induced systemic IgG, mucosal IgA, and cell-mediated response. The question still remains whether this mucosal vaccine will lead to reducing or even preventing $S$. aureus colonization in humans. It will be challenging for future research.

Further measures should be investigated, while meanwhile, transmission between positive and negative farms should be avoided. Therefore, it is advisable that farms check upon their MRSA status and if negative, they should only purchase animals from negative farms and take extreme care of vectors that may introduce MRSA in their farm.

\section{PERSPECTIVES}

Research performed so far indicates that MRSA CC398 has a high transmission potential and also a high probability to persist in the pig population at intensive farming. Moreover, these bacteria survive in the pig environment, which might furthermore act as an additional source of MRSA contamination. The control or eradication of MRSA CC398 from pig herds with intensive farming procedures can therefore be expected to be very difficult. Furthermore, the fact that MRSA CC398 currently appears as having a minor impact on pig health, questions the need of implementing expensive national eradication/control programs. Yet, the ability of MRSA CC398 to transfer from pigs (and other livestock) to humans is known as one of the primary concerns of its emergence. Indeed, persons in close contact with pigs are at higher risk to be colonized with MRSA CC398 (Voss et al., 2005; Denis et al., 2009; Mulders et al., 2010; van Cleef et al., 2010a,b). Still (human), infections and outbreaks are infrequently reported at the moment (Witte et al., 2007; van Rijen et al., 2008, 2009; Wulf et al., 2008b; Pan et al., 2009; Golding et al., 2010; Grundmann et al., 2010; Schijffelen et al., 2010). Moreover, 
it has been shown that MRSA CC398 has lower nosocomial transmissibility (Bootsma et al., 2011; Wassenberg et al., 2011) and virulence compared to other (hospital-associated) MRSA clones (van Rijen et al., 2008, 2009). Considering this, MRSA CC398 appears to be a less important public health threat compared to human-associated genotypes. Still, the ability of MRSA CC398 to acquire virulence and resistance genes incorporates the potential adaptation into more virulent strains. More importantly, these animal-associated bacteria are a reservoir of resistance genes (e.g., $c f r$ gene, which confers resistance to five different antimicrobial classes, including oxazolidinones such as linezolid, one of the few active drugs used for treating MRSA in human medicine and the vga genes, which as $c f r$, confer resistance to pleuromutilins also used in human and veterinary medicine (Kadlec

\section{REFERENCES}

Aarestrup, F. M., Cavaco, L., and Hasman, H. (2010). Decreased susceptibility to zinc chloride is associated with methicillin resistant Staphylococcus aureus CC398 in Danish swine. Vet. Microbiol. 142, 455-457.

Aarestrup, F. M., and Hasman, H. (2004). Susceptibility of different bacterial species isolated from food animals to copper sulphate, zinc chloride and antimicrobial substances used for disinfection. Vet. Microbiol. 100, 83-89.

Agersø, Y., Hasman, H., Cavaco, L. M., Pedersen, K., and Aarestrup, F. M. (2012). Study of methicillin resistant Staphylococcus aureus (MRSA) in Danish pigs at slaughter and in imported retail meat reveals a novel MRSA type in slaughter pigs. Vet. Microbiol. 157, 246-2450.

Alt, K., Fetsch, A., Schroeter, A., Guerra, B., Hammerl, J. A., Hertwig, S., et al. (2011). Factors associated with the occurrence of MRSA CC398 in herds of fattening pigs in Germany. BMC Vet. Res. 7:69. doi:10.1186/17466148-7-69

Amass, S. F., Arighi, M., Kinyon, J. M., Hoffman, L. J., Schneider, J. L., and Draper, D. K. (2006). Effectiveness of using a mat filled with a peroxygen disinfectant to minimize shoe sole contamination in a veterinary hospital. J. Am. Vet. Med. Assoc. 228, 1391-1396.

Anonymous. (2008). "Consumption of antimicrobial age and occurrence of antimicrobial resistance in bacteria from food animals, food and humans in Denmark," in The Danish Integrated Antimicrobial Resistance Monitoring and Research Programme (DANMAP) 2008, Copenhagen.

Anukool, U., O’Neill, C. E., Butr-Indr, B., Hawkey, P. M., Gaze, W. H., and
Wellington, E. M. (2011). Meticillinresistant Staphylococcus aureus in pigs from Thailand. Int. J. Antimicrob. Agents 38, 86-87.

Argudín, M. A., Tenhagen, B. A., Fetsch, A., Sachsenröder, J., Käsbohrer, A., Schroeter, A., et al. (2011). Virulence and resistance determinants of German Staphylococcus aureus ST398 isolates from nonhuman sources. Appl. Environ. Microbiol.77, 3052-3060.

Arlian, B. M., and Tinker, J. K. (2011). Mucosal immunization with a Staphylococcus aureus IsdA-cholera toxin A2/B chimera induces antigen-specific Th2-type responses in mice. Clin. Vaccine Immunol. 18, 1543-1551.

Armand-Lefevre, L., Ruimy, R., and Andremont, A. (2005). Clonal comparison of Staphylococcus aureus isolates from healthy pig farmers, human controls, and pigs. Emerg. Infect. Dis. 11, 711-714.

Arriola, C. S., Guere, M. E., Larsen, J., Skov, R. L., Gilman, R. H., Gonzalez, A. E., et al. (2011). Presence of methicillin-resistant Staphylococcus aureus in pigs in Peru. PLoS ONE 6:e28529. doi:10.1371/journal.pone.0028529

Battisti, A., Franco, A., Merialdi, G., Hasman, H., Iurescia, M., Lorenzetti, R., et al. (2010). Heterogeneity among methicillin-resistant Staphylococcus aureus from Italian pig finishing holdings. Vet. Microbiol. 142, 361-366.

Bisdorff, B., Scholholter, J. L., Claussen, K., Pulz, M., Nowak, D., and Radon, K. (2011). MRSA-ST398 in livestock farmers and neighbouring residents in a rural area in Germany. Epidemiol. Infect. 12, 1-9.

Bootsma, M. C., Wassenberg, M. W., Trapman, P., and Bonten, M. J. (2011). The nosocomial

et al., 2012) and might act as donor of these genes for HAMRSA and CA-MRSA clones, which could result in a major public health burden due to potential treatment failure (Vandendriessche et al., 2011b)). Hence, while eradication programs face a high potential for failure, it might be wiser to continuously survey the evolution (including the presence of virulence and resistance genes) of animal-associated MRSA among pigs (and other livestock).

\section{ACKNOWLEDGMENTS}

Financial support was received from the Institute for the Promotion of Innovation by Science and Technology in Flanders (IWT) project 070596 . M. A. Argudín is supported by a postdoctoral grant of the Fundación Alfonso Martín Escudero.

transmission rate of animalassociated ST398 methicillinresistant Staphylococcus aureus. J. $R$. Soc. Interface 8, 578-584.

Broens, E. M., Graat, E. A., Engel, B., van Oosterom, R. A., van de Giessen, A. W., and Van der Wolf, P. J. (2011a). Comparison of sampling methods used for MRSAclassification of herds with breeding pigs. Vet. Microbiol. 147, 440-444.

Broens, E. M., Graat, E. A., Van der Wolf, P. J., van de Giessen, A. W., and de Jong, M. C. (2011b). Prevalence and risk factor analysis of livestock associated MRSA-positive pig herds in The Netherlands. Prev. Vet. Med. 102 , 41-49.

Broens, E. M., Graat, E. A., Van der Wolf, P. J., van de Giessen, A. W. van Duijkeren E., Wagenaar, J. A., et al. (2011c). MRSA CC398 in the pig production chain. Prev. Vet. Med. 98 , 182-189.

Broens, E. M., Graat, E. A., Van der Wolf, P. J., van de Giessen, A. W., and de Jong, M. C. (2011d). Transmission of methicillin resistant Staphylococcus aureus among pigs during transportation from farm to abattoir. Vet. J. 189, 302-305.

Broens, E. M., Graat, E. A., van de Giessen, A. W., Broekhuizen-Stins, M. J., and de Jong, M. C. (2012a). Quantification of transmission of livestock-associated methicillin resistant Staphylococcus aureus in pigs. Vet. Microbiol. 155 , 381-388.

Broens, E. M., Espinosa-Gongora, C. Graat, E. A., Vendrig, N., van der Wolf, P. J., Guardabassi, L., et al. (2012b). Longitudinal study on transmission of MRSA CC398 within pig herds. BMC Vet. Res. 8:58. doi:10.1186/1746-6148-8-58

Burton, S., Reid-Smith, R., McClure, J. T., and Weese, J. S. (2008). Staphylococcus aureus colonization in healthy horses in Atlantic Canada. Can. Vet. J. 49, 797-799.

Busscher, J. F., van Duijkeren, E., and van Oldruitenborgh-Oosterbaan, M. M. S. (2006). The prevalence of methicillin-resistant staphylococci in healthy horses in the Netherlands. Vet. Microbiol. 113, 131-136.

Callens, B., Persoons, D., Maes, D., Laanen, M., Postma, M., Boyen, F., et al. (2012). Prophylactic and metaphylactic antimicrobial use in Belgian fattening pig herds. Prev. Vet. Med. 106, 53-62.

Campanile, F., Bongiorno, D., Falcone, M., Vailati, F., Pasticci, M. B., Perez, M., et al. (2011). Changing Italian nosocomial-community trends and heteroresistance in Staphylococcus aureus from bacteremia and endocarditis. Eur. J. Clin. Microbiol. Infect. Dis. 31, 739-745.

Cavaco, L. M., Hasman, H., and Aarestrup, F. M. (2011). Zinc resistance of Staphylococcus aureus of animal origin is strongly associated with methicillin resistance. Vet. Microbiol. 150, 344-348.

Cavaco, L. M., Hasman, H., Stegger, M., Andersen, P. S., Skov, R., Fluit, A. C., et al. (2010). Cloning and occurrence of czrC, a gene conferring cadmium and zinc resistance in MRSA CC398. Antimicrob. Agents Chemother. 54, 3605-3608.

Cefai, C., Ashurst, A. S., and Owens, C. (1994). Human carriage of methicillin-resistant Staphylococcus aureus linked with a pet dog. Lancet 344, 539-540.

Centers for Disease Control, and Prevention (CDC). (1999). Four pediatric deaths from communityacquired methicillin-resistant Staphylococcus aureus - Minnesota and Dakota, 1997-1999. JAMA 282, 1123-1125. 
Chambers, H. F. (2001). The changing epidemiology of Staphylococcus aureus? Emerg. Infect. Dis. 7, 178-182.

Crombé, F., Vanderhaeghen, W., de Vogel, C. P., Van Wamel, W. J., Barbé, K., Hermans, K., et al. (2013). Serological profiles in nursery piglets colonized with Staphylococcus aureus. Vet. Res. 44, 4.

Crombé, F., Willems, G., Dispas, M., Hallin, M., Denis, O., Suetens, C., et al. (2012a). Prevalence and antimicrobial susceptibility of methicillin-resistant Staphylococcus aureus among pigs in Belgium. Microbiol. Drug Resist. 18, 125-131.

Crombé, F., Vanderhaeghen, W., Dewulf, J., Hermans, K., Haesebrouck, F., and Butaye, P. (2012b). Colonization and transmission of methicillin-resistant Staphylococcus aureus ST398 in nursery piglets. Appl. Environ. Microbiol. 78, 1631-1634.

Cui, S., Li, J., Hu, C., Jin, S., Li, F., Guo, Y., et al. (2009). Isolation and characterization of methicillin-resistant Staphylococcus aureus from swine and workers in China. J. Antimicrob. Chemother. 64, 680-683.

Cuny, C., Friedrich, A., Kozytska, S., Layer, F., Nubel, U., Ohlsen, K., et al. (2010). Emergence of methicillin-resistant Staphylococcus aureus (MRSA) in different animal species. Int. J. Med. Microbiol. 300, 109-117.

Cuny, C., Friedrich, A. W., and Witte, W. (2012). Absence of livestockassociated methicillin-resistant Staphylococcus aureus clonal complex CC398 as a nasal colonizer of pigs raised in an alternative system. Appl. Environ. Microbiol. 78, 1296-1297.

Cuny, C., Nathaus, R., Layer, F., Strommenger, B., Altmann, D., and Witte, W. (2009). Nasal colonization of humans with methicillin-resistant Staphylococcus aureus (MRSA) CC398 with and without exposure to pigs. PLoS ONE 4:e6800. doi:10.1371/journal.pone.0006800

Cuny, C., Strommenger, B., Witte, W., and Stanek, C. (2008). Clusters of infections in horses with MRSA ST1, ST254, and ST398 in a veterinary hospital. Microb. Drug Resist. 214, 307-310.

David, M. Z., and Daum, R. S. (2010). Community-associated methicillinresistant Staphylococcus aureus: epidemiology and clinical consequences of an emerging epidemic. Clin. Microbiol. Rev. 23, 616-687.

Davies, P. R., Wagstrom, E. A., and Bender, J. B. (2011). Lethal necrotizing pneumonia caused by an ST398 Staphylococcus aureus strain. Emerg. Infect. Dis. 17, 1152-1153.

de Neeling, A. J., van den Broek, M. J., Spalburg, E. C., van SantenVerheuvel, M. G., Dam-Deisz, W. D., Boshuizen, H. C., et al. (2007). High prevalence of methicillin resistant Staphylococcus aureus in pigs. Vet. Microbiol. 122, 366-372.

Denis, O., Suetens, C., Hallin, M., Catry, B., Ramboer, I., Dispas, M., et al. (2009). Methicillin-resistant Staphylococcus aureus ST398 in swine farm personnel, Belgium. Emerg. Infect. Dis. 15, 1098-1101.

Deurenberg, R. H., and Stobberingh, E. E. (2009). The molecular evolution of hospital- and community-associated methicillinresistant Staphylococcus aureus. Curr. Mol. Med. 9, 100-115.

Deurenberg, R. H., Vink, C., Kalenic, S., Friedrich, A. W., Bruggeman, C. A., and Stobberingh, E. E. (2007). The molecular evolution of methicillin resistant Staphylococcus aureus. Clin. Microbiol. Infect. 13, 222-235.

Devriese, L. A., and Hommez, J. (1975). Epidemiology of methicillinresistant Staphylococcus aureus in dairy herds. Res. Vet. Sci. 19, 23-27.

Devriese, L. A., Van Damme, L. R., and Fameree, L. (1972). Methicillin(cloxacillin)-resistant Staphylococcus aureus 3468 strains isolated from bovine mastitis cases. Zentralbl. Veterinärmed. B. 19, 598-605.

Dewaele, I., Messens, W., De Man, I., Delputte, P., Herman, L., Butaye, P., et al. (2011). Sampling, prevalence and characterization of methicillinresistant Staphylococcus aureus on two Belgian pig farms. Vet. Sci. Dev. 1,1 .

Dressler, A. E., Scheibel, R. P., Wardyn, S., Harper, A. L., Hanson, B. M., Kroeger, J. S., et al. (2012). Prevalence, antibiotic resistance and molecular characterisation of Staphylococcus aureus in pigs at agricultural fairs in the USA. Vet. Rec. 170, 495.

Eames, I., Tang, J. W., Li, Y., and Wilson, P. (2009). Airborne transmission of disease in hospitals. J. R. Soc. Interface 6, 697-702.

Ekkelenkamp, M. B., Sekkat, M., Carpaij, N., Troelstra, A., and Bonten, M. J. M. (2006). Endocarditis due to meticillin-resistant Staphylococcus aureus originating from pigs. Ned. Tijdschr. Geneeskd. 150, 2442-2447.

Enright, M. C., Robinson, D. A., Randle, G., Feil, E. J., Grundmann, H., and Spratt, B. G. (2002). The evolutionary history of methicillin-resistant Staphylococcus aureus (MRSA). Proc. Natl. Acad. Sci. U.S.A. 99, 7687-7692.

Espinosa-Gongora, C., Larsen, J., Moodley, A., Nielsen, J. M. P., Skov, R. L., Andreasen, M., et al. (2012). Farm-specific lineages of methicillin-resistant Staphylococcus aureus clonal complex 398 in Danish pig farms. Epidemiol. Infect. 140, 1794-1799.

Espinosa-Gongora, C., Larsen, J., Moodley, A., Nielsen, J. P., Skov, R. L., Andreasen, M., et al. (2011). Farm-specific lineages of methicillin-resistant Staphylococcus aureus clonal complex 398 in Danish pig farms. Epidemiol. Infect. 25, 1-6. European Food Safety Authority (EFSA). (2009). Analysis of the baseline survey on the prevalence of methicillin-resistant Staphylococcus aureus (MRSA) in holdings with breeding pigs, in the EU, 2008. Part A: MRSA prevalence estimates; on request from the European Commission. EFSA J. 7, 1376.

European Food Safety Authority (EFSA). (2010). Analysis of the baseline survey on the prevalence of methicillin-resistant Staphylococcus aureus (MRSA) in holdings with breeding pigs, in the EU, 2008 - Part B: factors associated with MRSA contamination of holdings. EFSA $J$. 8, 1597.

Fall, C., Seck, A., Richard, V., Ndour, M., Sembene, M., Laurent, F., et al. (2012). Epidemiology of Staphylococcus aureus in pigs and farmers in the largest farm in Dakar, Senegal. Foodborne Pathog. Dis. 9, 962-965.

Feßler, A., Scott, C., Kadlec, K. Ehricht, R., Monecke, S., and Schwarz, S. (2010). Characterization of methicillin-resistant Staphylococcus aureus ST398 from cases of bovine mastitis. J. Antimicrob. Chemother. 65, 619-625.

Floras, A., Lawn, K., Slavic, D., Golding, G. R., Mulvey, M. R., and Weese, J. S. (2010). Sequence type 398 meticillin-resistant Staphylococcus aureus infection and colonisation in dogs. Vet. Rec. 166, 826-827.

Fluit, A. C. (2012). Livestock-associated Staphylococcus aureus. Clin. Microbiol. Infect. 18, 735-744.

Friese, A., Schulz, J., Hoehle, L., Fetsch, A., Tenhagen, B. A., Hartung, J., et al. (2012). Occurrence of MRSA in air and housing environment of pig barns. Vet. Microbiol. 158, 129-135.

Garcia-Graells, C., Antoine, J., Larsen, J., Catry, B., Skov, R., and Denis, O. (2012). Livestock veterinarians at high risk of acquiring methicillin-resistant Staphylococcus aureus ST398. Epidemiol. Infect. 140, 383-389.

Gibbs, S. G., Green, C. F., Tarwater, P. M., Mota, L. C., Mena, K. D., and Scarpino, P. V. (2006). Isolation of antibiotic-resistant bacteria from the air plume downwind of a swine confined or concentrated animal feeding operation. Environ. Health Perspect. 114, 1032-1037.

Gilbert, M. J., Bos, M. E., Duim, B. Urlings, B. A., Heres, L., Wagenaar, J. A., et al. (2012). Livestockassociated MRSA ST398 carriage in pig slaughterhouse workers related to quantitative environmental exposure. Occup. Environ. Med. 69, 472-478.

Golding, G. R., Bryden, L., Levett, P. N., McDonald, R. R., Wong, A., Wylie, J., et al. (2010). Livestock-associated methicillin-resistant Staphylococcus aureus sequence type 398 in humans, Canada. Emerg. Infect. Dis. 16, 587-594.

Gómez-Sanz, E., Torres, C., Lozano, C., Fernández-Pérez, R., Aspiroz, C., Ruiz-Larrea, F., et al. (2010). Detection, molecular characterization, and clonal diversity of methicillin-resistant Staphylococcus aureus CC398 and CC97 in Spanish slaughter pigs of different age groups. Foodborne Pathog. Dis. 7, 1269-1277.

Goni, P., Vergara, Y., Ruiz, J., Albizu, I., Vila, J., and Gomez-Lus, R. (2004). Antibiotic resistance and epidemiological typing of Staphylococcus aureus strains from ovine and rabbit mastitis. Int. J. Antimicrob. Agents 23, 268-272.

Graffunder, E. M., and Venezia, R. A. (2002). Risk factors associated with nosocomial methicillin-resistant Staphylococcus aureus (MRSA) infection including previous use of antimicrobials. J. Antimicrob. Chemother. 49, 999-1005.

Graveland, H., van Duijkeren, E., van Nes, A., Schoormans, A., Broekhuizen-Stins, M., Oosting-van Schothorst, I., et al. (2009). Evaluation of isolation procedures and chromogenic agar media for the detection of MRSA in nasal swabs from pigs and veal calves. Vet. Microbiol. 139, 121-125.

Graveland, H., Wagenaar, J. A., Bergs, K., Heesterbeek, H., and Heederik, D. (2011). Persistence of livestock associated MRSA CC398 in humans is dependent on intensity of animal contact. PLOS ONE 6:e16830. doi:10.1371/journal.pone.0016830

Graveland, H., Wagenaar, J. A., Heesterbeek, H., Mevius, D., van Duijkeren, E., and Heederik, D. (2010). 
Methicillin resistant Staphylococcus aureus ST398 in veal calf farming: human MRSA carriage related with animal antimicrobial usage and farm hygiene. PLOS ONE 5:e10990. doi:10.1371/journal.pone.0010990

Grundmann, H., Aanensen, D. M., van den Wijngaard, C. C., Spratt, B. G., Harmsen, D., Friedrich, A. W., et al. (2010). Geographic distribution of Staphylococcus aureus causing invasive infections in Europe: a molecular-epidemiological analysis. PLoS Med. 7:e1000215. doi:10.1371/journal.pmed.1000215

Grundmann, H., Aires-de-Sousa, M., Boyce, J., and Tiemersma, E. (2006). Emergence and resurgence of meticillin-resistant Staphylococcus aureus as a public-health threat. Lancet 368, 874-885.

Grundmann, H., Hori, S., Winter, B., Tami, A., and Austin, D. J. (2002). Risk factors for the transmission of methicillin-resistant Staphylococcus aureus in an adult intensive care unit: fitting a model to the data. $J$. Infect. Dis. 185, 481-488.

Guardabassi, L., O'Donoghue, M., Moodley, A., Ho, J., and Boost, M. (2009). Novel lineage of methicillinresistant Staphylococcus aureus, Hong Kong. Emerg. Infect. Dis. 15, 1998-2000.

Guardabassi, L., Stegger, M., and Skov, R. (2007). Retrospective detection of methicillin resistant and susceptible Staphylococcus aureus ST398 in Danish slaughter pigs. Vet. Microbiol. 122, 384-386.

Habrun, B., Racic, I., Beck, R., Budimir, A., Benic, M., Kompes, G., et al. (2011). The presence of methicillinresistant Staphylococcus aureus on large pig breeding farms in Croatia. Acta Vet. Hung. 59, 419-425.

Haenni, M., Châtre, P., Boisset, S., Carricajo, A., Bes, M., Laurent, F., et al. (2011). Staphylococcal nasal carriage in calves: multiresistant Staphylococcus sciuri and immune evasion cluster (IEC) genes in methicillin-resistant Staphylococcus aureus ST398. J. Antimicrob. Chemother. 66, 1927-1928.

Haenni, M., Saras, E., Chatre, P., Medaille, C., Bes, M., Madec, J. Y., et al. (2012). A USA300 variant and other human-related methicillin-resistant Staphylococcus aureus strains infecting cats and dogs in France. J. Antimicrob. Chemother. 67, 326-329.

Hallin, M., De Mendonca, R., Denis, O., Lefort, A., El Garch, F., Butaye, P., et al. (2011). Diversity of accessory genome of human and livestock-associated ST398 methicillin resistant Staphylococcus aureus strains. Infect. Genet. Evol. $11,290-299$.

Hartmann, M. S., Trostle, S. S., and Klohnen, A. A. (1997). Isolation of methicillin-resistant Staphylococcus aureus from a post-operative wound infection in a horse. J. Am. Vet. Assoc. $211,590-592$.

Hasman, H., Kempf, I., Chidaine, B., Cariolet, R., Ersbøll, A. K., Houe, H., et al. (2006). Copper resistance in Enterococcus faecium, mediated by the tcrB gene, is selected by supplementation of pig feed with copper sulfate. Appl. Environ. Microbiol. 72, 5784-5789.

Hermans, K., Devriese, L. A., and Haesebrouck, F. (2010). "Staphylococcus in Gyles CL," Pathogenesis of Bacterial Infections in Animals, 4th Edn, eds J. F. Prescott, J. G. Songer, and C. O. Thoen (Oxford: Wiley-Blackwell), 75-89.

Hermans, K., Lipinska, U., Denis, O., Deplano, A., Struelens, M. J., Nemati, M., et al. (2008). MRSA clone ST398-SCCmec IV as a cause of infections in an equine clinic. Vlaams Diergeneeskundig Tijdschrift 77, 429-433.

Hill, G. M., Cromwell, G. L., Crenshaw, T. D., Dove, C. R., Ewan, R. C., Knabe, D. A., et al. (2000). Growth promotion effects and plasma changes from feeding high dietary concentrations of zinc and copper to weanling pigs (regional study). J. Anim. Sci. 78, 1010-1016.

Holmes, M. A., and Zadoks, R. N. (2011). Methicillin resistant S. aureus in human and bovine mastitis. J. Mammary Gland Biol. Neoplasia 16, 373-382.

Holtfreter, S., Kolata, J., and Broke, B. M. (2010). Towards the immune proteome of Staphylococcus aureus - the anti-S. aureus antibody response. Int. J. Med. Microbiol. 300, 176-192.

Horgan, M., Abbott, Y., Lawlor, P. G., Rossney, A., Coffey, A., Fitzgerald, G. F., et al. (2011). A study of the prevalence of methicillin-resistant Staphylococcus aureus in pigs and in personnel involved in the pig industry in Ireland. Vet. J. 190, 255-259.

Huber, H., Koller, S., Giezendanner, N., Stephan, R., and Zweifel, C. (2010). Prevalence and characteristics of meticillin-resistant Staphylococcus aureus in humans in contact with farm animals, in livestock, and in food of animal origin, Switzerland, 2009. Euro Surveill. 15:19542.

Huijsdens, X. W., van Dijke, B. J., Spalburg, E., van Santen-Verheuvel, M. G., Heck, M. E., Pluister, G. N., et al. (2006). Community-acquired
MRSA and pig-farming. Ann. Clin. Microbiol. Antimicrob. 5, 26.

Ito, T., Ma, X. X., Takeuchi, F., Okuma, K., Yuzawa, H., and Hiramatsu, K. (2004). Novel type V staphylococcal cassette chromosome mec driven by a novel cassette chromosome recombinase, $c c r C$. Antimicrob. Agents Chemother. 48, 2637-2651.

Jacela, J. Y., DeRouchey, J. M., Tokach, M. D., Goodband, R. D., Nelssen, J. L., Renter, D. G., et al. (2010). Feed additives for swine: fact sheets - high dietary levels of copper and zinc for young pigs, and phytase. J. Swine Health Prod. 18, 87-91.

Jensen, S. O., and Lyon, B. R. (2009). Genetics of antimicrobial resistance in Staphylococcus aureus. Future Microbiol. 4, 565-582.

Jevons, M. P. (1961). 'Celbenin'resistant Staphylococci. Br. Med. J. 1, 124-125.

Jouy, E., Le, R. A., Keranflec'h, A., Granier, S. A., Laurent, F., Kempf, I., et al. (2012). Methicillin-resistant Staphylococcus aureus ST398 contamination and transmission in pigs after a low dose inoculation. Lett. Appl. Microbiol. 54, 518-523.

Kadlec, K., Ehricht, R., Monecke, S., Steinacker, U., Kaspar, H., Mankertz, J., et al. (2009). Diversity of antimicrobial resistance pheno- and genotypes of methicillin-resistant Staphylococcus aureus ST398 from diseased swine. J. Antimicrob. Chemother. 64, 1156-1164.

Kadlec, K., Feler, A. T., Hauschild, T., and Schwarz, S. (2012). Novel and uncommon antimicrobial resistance genes in livestock-associated methicillin-resistant Staphylococcus aureus. Clin. Microbiol. Infect. 18, 745-755.

Kadlec, K., Pomba, C. F., Couto, N., and Schwarz, S. (2010). Small plasmids carrying $v g a(\mathrm{~A})$ or $v g a(\mathrm{C})$ genes mediate resistance to lincosamides, pleuromutilins and streptogramin A antibiotics in methicillin-resistant Staphylococcus aureus ST398 from swine. J. Antimicrob. Chemother. 65 , 2692-2693.

Kadlec, K., and Schwarz, S. (2009). Novel ABC transporter gene, $v g a(C)$, located on a multiresistance plasmid from a porcine methicillin-resistant Staphylococcus aureus ST398 strain. Antimicrob. Agents Chemother. 53, 3589-3591.

Katouli, M., Melin, L., Jensen-Waern, M., Wallgren, P., and Möllby, R. (1999). The effect of zinc oxide supplementation on the stability of the intestinal flora with special reference to composition of coliforms in weaned pigs. J. Appl. Microbiol. 87, 564-573.

Kehrenberg, C., Cuny, C., Strommenger, B., Schwarz, S., and Witte, W. (2009). Methicillin-resistant and -susceptible Staphylococcus aureus strains of clonal lineages ST398 and ST9 from swine carry the multidrug resistance gene cfr. Antimicrob. Agents Chemother. 53, 779-781.

Khanna, T., Friendship, R., Dewey, C., and Weese, J. S. (2008). Methicillin resistant Staphylococcus aureus colonization in pigs and pig farmers. Vet. Microbiol. 128, 298-303.

Kluytmans-VandenBergh, M. F., and Kluytmans, J. A. (2006). Community-acquired methicillinresistant Staphylococcus aureus: current perspectives. Clin. Microbiol. Infect. 12, 9-15.

Köck, R., Harlizius, J., Bressan, N., Laerberg, R., Wieler, L. H., Witte, W., et al. (2009). Prevalence and molecular characteristics of methicillin-resistant Staphylococcus aureus (MRSA) among pigs on German farms and import of livestock-related MRSA into hospitals. Eur. J. Clin. Microbiol. Infect. Dis. 28, 1375-1382.

Köck, R., Loth, B., Köksal, M., SchulteWülwer, J., Harlizius, J., and Friedrich, A. W. (2012). Persistence of nasal colonization with livestock-associated methicillinresistant Staphylococcus aureus in pig farmers after holidays from pig exposure. Appl. Environ. Microbiol. 78, 4046-4047.

Kondo, Y., Ito, T., Ma, X. X., Watanabe, S., Kreiswirth, B. N., Etienne, J. et al. (2007). Combination of multiplex PCRs for staphylococcal cassette chromosome mec type assignment: rapid identification system for mec, $c c r$, and major differences in junkyard regions. Antimicrob. Agents Chemother. 51, 264-274.

Krziwanek, K., Metz-Gercek, S., and Mittermayer, H. (2009). MethicillinResistant Staphylococcus aureus ST398 from human patients, upper Austria. Emerg. Infect. Dis. 15, 766-769.

Larsen, J., Imanishi, M., Hinjoy, S., Tharavichitkul, P., Duangsong, K., Davis, M. F., et al. (2012). Methicillin-resistant Staphylococcus aureus ST9 in pigs in Thailand. PLoS ONE 7:e31245. doi:10.1371/journal.pone.0031245

Lee, J. H. (2003). Methicillin (oxacillin)resistant Staphylococcus aureus strains isolated from major food animals and their potential transmission to humans. Appl. Environ. Microbiol. 69, 6489-6494. 
Lewis, H. C., Molbak, K., Reese, C., Aarestrup, F. M., Selchau, M., Sorum, M., et al. (2008). Pigs as source of methicillin-resistant Staphylococcus aureus CC398 infections in humans, Denmark. Emerg. Infect. Dis. 14, 1383-1389.

Li, S., Skov, R. L., Han, X., Larsen, A. R., Larsen, J., Sørum, M., et al. (2011). Novel types of staphylococcal cassette chromosome mec elements identified in clonal complex 398 methicillin-resistant Staphylococcus aureus strains. Antimicrob. Agents Chemother. 55, 3046-3050.

Lim, S. K., Nam, H. M., Jang, G. C., Lee, H. S., Jung, S. C., and Kwak, H. S. (2012). The first detection of methicillin-resistant Staphylococcus aureus ST398 in pigs in Korea. Vet. Microbiol. 155, 88-92.

Lo, Y. P., Wan, M. T., Chen, M. M., Su, H. Y., Lauderdale, T. L., and Chou, C. C. (2012). Molecular characterization and clonal genetic diversity of methicillin-resistant Staphylococcus aureus of pig origin in Taiwan. Comp. Immunol. Microbiol. Infect. Dis. 35, 513-521.

Loeffler, A., and Lloyd, D. H. (2010). Companion animals: a reservoir for methicillin-resistant Staphylococcus aureus in the community? Epidemiol. Infect. 138, 595-605.

Lowder, B. V., Guinane, C. M., Ben Zakour, N. L., Weinert, L. A., Conway-Morris, A., Cartwright, R. A., et al. (2009). Recent human-topoultry host jump, adaptation, and pandemic spread of Staphylococcus aureus. Proc. Natl. Acad. Sci. U S A. 106, 19545-19550.

Lowy, F. D. (2003). Antimicrobial resistance: the example of Staphylococcus aureus. J. Clin. Invest. 111, 1265-1273.

Lozano, C., Aspiroz, C., Ara, M., Gomez-Sanz, E., Zarazaga, M., and Torres, C. (2011a). Methicillinresistant Staphylococcus aureus (MRSA) ST398 in a farmer with skin lesions and in pigs of his farm: clonal relationship and detection of $\operatorname{lnu}(\mathrm{A})$ gene. Clin. Microbiol. Infect. 17, 923-927.

Lozano, C., Aspiroz, C., Charlez, L., Gomez-Sanz, E., Toledo, M., Zarazaga, M., et al. (2011b). Skin lesion by methicillin-resistant Staphylococcus aureus ST398-t1451 in a Spanish pig farmer: possible transmission from animals to humans. Vector Borne Zoonotic Dis. 11, 605-607.

Lozano, C., Aspiroz, C., Rezusta, A., Gómez-Sanz, E., Simon, C., Gómez, P., et al. (2012). Identification of novel $v g a(\mathrm{~A})$-carrying plasmids and a Tn5406-like transposon in meticillin-resistant Staphylococcus aureus and Staphylococcus epidermidis of human and animal origin. Int. J. Antimicrob. Agents 40, 306-312.

Malachowa, N., and DeLeo, F. R. (2010). Mobile genetic elements of Staphylococcus aureus. Cell. Mol. Life Sci. 67, 3057-3071.

Mammina, C., Cala, C., Plano, M. R., Bonura, C., Vella, A., Monastero, R. et al. (2010). Ventilator-associated pneumonia and MRSA ST398, Italy. Emerg. Infect. Dis. 16, 730-731.

Mandell, G. L., Bennett, J. E., and Dolin, R. (2000). "Staphylococcus aureus (including Staphylococcal toxic shock)," in Bennett's-Principles and Practice of Infectious Diseases, eds G. L. Mandell, J. E. Bennett, and R. Dolin (Philadelphia: Churchill Livingstone).

Manian, F. A. (2003). Asymptomatic nasal carriage of mupirocinresistant, methicillin-resistant Staphylococcus aureus (MRSA) in a pet dog associated with MRSA infection in household contacts. Clin. Infect. Dis. 36, e26-e28.

Massey, R. C., Horsburgh, M. J., Lina, G., Hook, M., and Recker, M. (2006). The evolution and maintenance of virulence in Staphylococcus aureus: a role for host-to-host transmission? Nat. Rev. Microbiol. 4 953-958.

Meemken, D., Blaha, T., Tegeler, R., Tenhagen, B. A., Guerra, B., Hammerl, J. A., et al. (2010). Livestock associated methicillin-resistant Staphylococcus aureus (LA-MRSA) isolated from lesions of pigs at necropsy in northwest Germany between 2004 and 2007. Zoonoses Public Health 57, e143-e148.

Meemken, D., Cuny, C., Witte, W., Eichler, U., Staudt, R., and Blaha, T. (2008). Occurrence of MRSA in pigs and in humans involved in pig production - preliminary results of a study in the northwest of Germany. Dtsch. Tierarztl. Wochenschr. 115, 132-139.

Meerburg, B. G., Jacobs-Reitsma, W. F., Wagenaar, J. A., and Kijlstra, A. (2006). Presence of Salmonella and Campylobacter spp. in wild small mammals on organic farms. Appl. Environ. Microbiol. 72, 960-962.

Mendes, R. E., Smith, T. C., Deshpande, L., Diekema, D. J., Sader, H. S., and Jones, R. N. (2011). Plasmidborne vga(A)-encoding gene in methicillin-resistant Staphylococcus aureus ST398 recovered from swine and a swine farmer in the United
States. Diagn. Microbiol. Infect. Dis. 71, 177-180.

Molla, B., Byrne, M., Abley, M., Mathews, J., Jackson, C. R., Fedorka-Cray, P., et al. (2012). Epidemiology and genotypic characteristics of methicillin-resistant Staphylococcus aureus (MRSA) of porcine origin. J. Clin. Microbiol. 50, 3687-3693.

Monecke, S., Coombs, G., Shore, A. C. Coleman, D. C., Akpaka, P., Borg, M., et al. (2011). A field guide to pandemic, epidemic and sporadic clones of methicillin-resistant Staphylococcus aureus. PLOS ONE 6:e17936. doi:10.1371/journal.pone.0017936

Monecke, S., Kuhnert, P., Hotzel, H., Slickers, P., and Ehricht, R. (2007). Microarray based study on virulence-associated genes and resistance determinants of Staphylococcus aureus isolates from cattle. Vet. Microbiol. 125, 128-140.

Monecke, S., Ruppelt, A., Wendlandt, S., Schwarz, S., Slickers, P., Ehricht, R., et al. (2013). Genotyping of Staphylococcus aureus isolates from diseased poultry. Vet. Microbiol. 162, 806-812.

Moodley, A., Nielsen, S. S., and Guardabassi, L. (2011a). Effects of tetracycline and zinc on selection of methicillin-resistant Staphylococcus aureus (MRSA) sequence type 398 in pigs. Vet. Microbiol. 152, 420-423.

Moodley, A., Latronico, F., and Guardabassi, L. (2011b). Experimental colonization of pigs with methicillin-resistant Staphylococcus aureus (MRSA): insights into the colonization and transmission of livestock-associated MRSA. Epidemiol. Infect. 139, 1594-1600.

Mooij, R., Toelstra, A., Jenkins, J. M., and Thijsen, S. F. T. (2007). MRSA in calves. Infectieziekten Bull. 18, 234-236.

Morcillo, A., Castro, B., RodríguezÁlvarez, C., González, J. C., Sierra, A., Montesinos, M. I., et al. (2012). Prevalence and characteristics of methicillin-resistant Staphylococcus aureus in pigs and pig workers in Tenerife, Spain. Foodborne Pathog. Dis. 9, 207-210.

Mulders, M. N., Haenen, A. P., Geenen, P. L., Vesseur, P. C., Poldervaart, E. S., Bosch, T., et al. (2010). Prevalence of livestock-associated MRSA in broiler flocks and risk factors for slaughterhouse personnel in The Netherlands. Epidemiol. Infect. 138, 743-755.

Naimi, T. S., LeDell, K. H., ComoSabetti, K., Borchardt, S. M., Boxrud, D. J., Etienne, J., et al. (2003). Comparison of community- and healthcare-associated methicillin-resistant Staphylococcus aureus infection. JAMA 290, 2976-2984.

Neela, V., Mohd, Z. A., Mariana, N. S., van Belkum, A., Liew, Y. K., and Rad, E. G. (2009). Prevalence of ST9 methicillin-resistant Staphylococcus aureus among pigs and pig handlers in Malaysia. J. Clin. Microbiol. 47, 4138-4140.

Nemati, M., Hermans, K., Lipinska, U., Denis, O., Deplano, A., Struelens, M., et al. (2008). Antimicrobial resistance of old and recent Staphylococcus aureus isolates from poultry: first detection of livestock-associated methicillin-resistant strain ST398. Antimicrob. Agents Chemother. 52, 3817-3819.

Nienhoff, U., Kadlec, K., Chaberny, I. F., Verspohl, J., Gerlach, G. F., Schwarz, S., et al. (2009). Transmission of methicillin-resistant Staphylococcus aureus strains between humans and dogs: two case reports. J. Antimicrob. Chemother. 64, 660-662.

O’Brien, A. M., Hanson, B. M., Farinam, S. A., Wu, J. Y., Simmering, J. E., Wardyn, S. E., et al. (2012). MRSA in conventional and alternative retail pork products. PLoS ONE 7:e30092. doi:10.1371/journal.pone.0030092

O'Brien, F. G., Pearman, J. W., Gracey, M., Riley, T. V., and Grubb, W. B. (1999). Community strain of methicillin-resistant Staphylococcus aureus involved in a hospital outbreak. J. Clin. Microbiol. 37, 2858-2862.

Okuma, K., Iwakawa, K., Turnidge, J. D., Grubb, W. B., Bell, J. M., O'Brien, F. G., et al. (2002). Dissemination of new methicillin-resistant Staphylococcus aureus clones in the community. J. Clin. Microbiol. 40, 4289-4294.

Osadebe, L. U., Hanson, B., Smith, T. C., and Heimer, R. (2012). Prevalence and characteristics of Staphylococcus aureus in Connecticut swine and swine farmers. Zoonoses Public Health. doi:10.1111/j.18632378.2012.01527.x

Overesch, G., Buttner, S., Rossano, A., and Perreten, V. (2011). The increase of methicillin-resistant Staphylococcus aureus (MRSA) and the presence of an unusual sequence type ST49 in slaughter pigs in Switzerland. BMC Vet. Res. 7:30. doi:10.1186/17466148-7-30

Pan, A., Battisti, A., Zoncada, A., Bernieri, F., Boldini, M., Franco, A., et al. (2009). Community-acquired methicillin-resistant Staphylococcus aureus ST398 infection, Italy. Emerg. Infect. Dis. 15, 845-847. 
Persoons, D., Van Hoorebeke, S., Hermans, K., Butaye, P., de Kruif, A., Haesebrouck, F., et al. (2009). Methicillin-resistant Staphylococcus aureus in poultry. Emerg. Infect. Dis. 15, 452-453.

Pletinckx, L. J., Verhegghe, M., Crombé, F., Dewulf, J., Goddeeris, B. M., and De Man, I. (2012). "Preliminary results on MRSA prevalence and spread in livestock species on Belgian pig farms and mixed pig farms," in Proceedings of the 4th European Symposium of Porcine Health Management (ESPHM) April, Bruges, 25-27.

Pletinckx, L. J., Verhegghe, M., Dewulf, J., Crombé, F., De Bleecker, Y., Rasschaert, G., et al. (2011). Screening of poultry-pig farms for methicillinresistant Staphylococcus aureus: sampling methodology and within herd prevalence in broiler flocks and pigs. Infect. Genet. Evol. 11, 2133-2137.

Pomba, C., Hasman, H., Cavaco, L. M., da Fonseca, J. D., and Aarestrup, F. M. (2009). First description of meticillin-resistant Staphylococcus aureus (MRSA) CC30 and CC398 from swine in Portugal. Int. J. Antimicrob. Agents 34, 193-194.

Porrero, M. C., Wassenaar, T. M., Gómez-Barrero, S., García, M., Bárcena, C., Alvarez, J., et al. (2012). Detection of methicillinresistant Staphylococcus aureus in Iberian pigs. Lett. Appl. Microbiol.54, 280-285.

Price, L. B., Stegger, M., Hasman, H., Aziz, M., Larsen, J., Andersen, P. S., et al. (2012). Staphylococcus aureus CC398: host adaptation and emergence of methicillin resistance in livestock. mBio 3, e00305-e00311.

Robinson, D. A., and Enright, M. C. (2003). Evolutionary models of the emergence of methicillin-resistant Staphylococcus aureus. Antimicrob. Agents Chemother. 47, 3926-3934.

Rubin, J. E., Ball, K. R., and ChirinoTrejo, M. (2011). Decreased susceptibility of MRSA ST398 to tiamulin. Vet. Microbiol. 151, 422-423.

Saiman, L., O’Keefe, M., Graham, P. L. III, Wu, F., Said-Salim, B., Kreiswirth, B., LaSala, A., et al. (2003). Hospital transmission of community-acquired methicillinresistant Staphylococcus aureus among postpartum women. Clin. Infect. Dis. 37, 1313-1319.

Sakwinska, O., Giddey, M., Moreillon, M., Morisset, D., Waldvogel, A., and Moreillon, P. (2011). Staphylococcus aureus host range and humanbovine host shift. Appl. Environ. Microbiol. 77, 5908-5915.

Salmenlinna, S., Lyytikainen, O., Vainio, A., Myllyniemi, A. L., Raulo, S.,
Kanerva, M., et al. (2010). Human Cases of methicillin-resistant Staphylococcus aureus CC398, Finland. Emerg. Infect. Dis. 16, 1626-1629.

Schijffelen, M. J., Boel, C. H., van Strijp, J. A., and Fluit, A. C. (2010). Whole genome analysis of a livestockassociated methicillin-resistant Staphylococcus aureus ST398 isolate from a case of human endocarditis. BMC Genomics 11:376. doi:10.1186/1471-2164-11-376

Schulz, J., Friese, A., Klees, S., Tenhagen, B. A., Fetsch, A., Rösler, U., et al. (2012). LA-MRSA contamination of air and soil surfaces in the vicinity of pig barns: a longitudinal study. Appl. Environ. Microbiol. 78, 5666-5671.

Schwarz, S., Kadlec, K., and Strommenger, B. (2008). Methicillinresistant Staphylococcus aureus and Staphylococcus pseudintermedius detected in the Bft-GermVet monitoring programme 2004-2006 in Germany. J. Antimicrob. Chemother. 61, 282-285.

Schwendener, S., and Perreten, V. (2011). New transposon Tn6133 in methicillin-resistant Staphylococcus aureus ST398 contains $v g a(\mathrm{E})$, a novel streptogramin A, pleuromutilin, and lincosamide resistance gene. Antimicrob. Agents Chemother. 55, 4900-4904.

Scott, G. M., Thomson, R., Malone-Lee, J., and Ridgway, G. L. (1988). Crossinfection between animals and man: possible feline transmission of Staphylococcus aureus infection in humans? J. Hosp. Infect. 12, 29-34.

Sergio, D. M., Koh, T. H., Hsu, L. Y., Ogden, B. E., Goh, A. L., and Chow, P. K. (2007). Investigation of meticillin-resistant Staphylococcus aureus in pigs used for research. $J$. Med. Microbiol. 56, 1107-1109.

Sieber, S., Gerber, V., Jandova, V., Rossano, A., Evison, J. M., and Perreten, V. (2011). Evolution of multidrug-resistant Staphylococcus aureus infections in horses and colonized personnel in an equine clinic between 2005 and 2010. Microb. Drug Resist. 17, 471-478.

Sing, A., Tuschak, C., and Hormansdorfer, S. (2008). Methicillin-resistant Staphylococcus aureus in a family and its pet cat. N. Engl. J. Med. 358, 1200-1201.

Smith, T. C., Male, M. J., Harper, A. L., Kroeger, J. S., Tinkler, G. P., Moritz, E. D., et al. (2009). Methicillinresistant Staphylococcus aureus (MRSA) strain ST398 is present in midwestern U.S. swine and swine workers. PLoS ONE 4:e4258. doi:10.1371/journal.pone.0004258
Smyth, D. S., Feil, E. J., Meaney, W. J., Hartigan, P. J., Tollersrud, T., Fitzgerald, J. R., et al. (2009). Molecular genetic typing reveals further insights into the diversity of animalassociated Staphylococcus aureus. J. Med. Microbiol. 58, 1343-1353.

Soavi, L., Stellini, R., Signorini, L., Antonini, B., Pedroni, P., Zanetti, L., et al. (2010). Methicillinresistant Staphylococcus aureus ST398, Italy. Emerg. Infect. Dis. 16, 346-348.

Song, J. H., Hsueh, P. R., Chung, D. R., Ko, K. S., Kang, C. I., Peck, K. R., et al. (2011). Spread of methicillin-resistant Staphylococcus aureus between the community and the hospitals in Asian countries: an ANSORP study. J. Antimicrob. Chemother. 66, 1061-1069.

Spohr, M., Rau, J., Friedrich, A., Klittich, G., Fetsch, A., Guerra, B., et al. (2011). Methicillin-resistant Staphylococcus aureus (MRSA) in three dairy herds in southwest Germany. Zoonoses Public Health 58, 252-261.

Stefani, S., Chung, D. R., Lindsay, J. A., Friedrich, A. W., Kearns, A. M., Westh, H., et al. (2012). Meticillin-resistant Staphylococcus aureus (MRSA): global epidemiology and harmonisation of typing methods. Int. J. Antimicrob. Agents 39, 273-282.

Stegger, M., Lindsay, J. A., Sørum, M., Gould, K. A., and Skov, R. (2010). Genetic diversity in CC398 methicillin-resistant Staphylococcus aureus isolates of different geographical origin. Clin. Microbiol. Infect. 16, 1017-1019.

Szabó, I., Beck, B., Friese, A., Fetsch, A., Tenhagen, B. A., and Roesler, U. (2012). Colonization kinetics of different methicillin-resistant Staphylococcus aureus sequence types in pigs and host susceptibilities. Appl. Environ. Microbiol. 78, 541-548.

Tacconelli, E., De, A. G., Cataldo, M. A., Pozzi, E., and Cauda, R. (2008). Does antibiotic exposure increase the risk of methicillinresistant Staphylococcus aureus (MRSA) isolation? A systematic review and meta-analysis. J. Antimicrob. Chemother. 61, 26-38.

Tenhagen, B. A., Fetsch, A., Stuhrenberg, B., Schleuter, G., Guerra, B., Hammerl, J. A., et al. (2009). Prevalence of MRSA types in slaughter pigs in different German abattoirs. Vet. Rec. 165, 589-593.

Tenover, F. C., McDougal, L. K., Goering, R. V., Killgore, G., Projan, S. J., Patel, J. B., et al. (2006).
Characterization of a strain of community-associated methicillinresistant Staphylococcus aureus widely disseminated in the United States. J. Clin. Microbiol. 44, 108-118.

Tsai, H. Y., Liao, C. H., Cheng, A., Liu, C. Y., Huang, Y. T., Teng, L. J., et al. (2012). Isolation of meticillin-resistant Staphylococcus aureus sequence type 9 in pigs in Taiwan. Int. J. Antimicrob. Agents 39, 449-451.

Turlej, A., Hryniewicz, W., and Empel, J. (2011). Staphylococcal cassette chromosome mec (SCCmec) classification and typing methods: an overview. Pol. J. Microbiol. 60, 95-103.

Udo, E. E., Pearman, J. W., and Grubb, W. B. (1993). Genetic analysis of community isolates of methicillinresistant 4357 Staphylococcus aureus in Western Australia. J. Hosp. Infect. 25, 97-108.

van Belkum, A., Melles, D. C., Peeters, J. K., van Leeuwen, W. B., van Duijkeren, E., Huijsdens, X. W., et al. (2008). Methicillin-resistant and -susceptible Staphylococcus aureus sequence type 398 in pigs and humans. Emerg. Infect. Dis. 14, 479-483.

van Belkum, A., Verkaik, N. J., de Vogel, C. P., Boelens, H. A., Verveer, J. Nouwen, J. L., et al. (2009). Reclassification of Staphylococcus aureus nasal carriage types. J. Infect. Dis. 199, 1820-1826.

van Cleef, B. A., Broens, E. M., Voss, A. Huijsdens, X. W., Zuchner, L., Van Benthem, B. H., et al. (2010a). High prevalence of nasal MRSA carriage in slaughterhouse workers in contact with live pigs in The Netherlands. Epidemiol. Infect. 138, 756-763.

van Cleef, B. A., Verkade, E. J., Wulf, M. W., Buiting, A. G., Voss, A., Huijsdens, X. W., et al. (2010b). Prevalence of livestockassociated MRSA in communities with high pig-densities in The Netherlands. PLOS ONE 5:e9385. doi:10.1371/journal.pone.0009385

van Cleef, B. A., Graveland, H., Haenen, A. P., van de Giessen, A. W., Heederik, D., Wagenaar, J. A., et al. (2012). Persistence of livestock-associated methicillin-resistant Staphylococcus aureus in field workers after shortterm occupational exposure to pigs and veal calves. J. Clin. Microbiol. 49, 1030-1033.

van Cleef, B. A., Monnet, D. L., Voss, A., Krziwanek, K., Allerberger, F., Struelens, M., et al. (2011). Livestock-associated methicillinresistant Staphylococcus aureus in 
Humans, Europe. Emerg. Infect. Dis. 17, 502-505.

van de Giessen, A. W., van SantenVerheuvel, M. G., Hengeveld, P. D., Bosch, T., Broens, E. M., and Reusken, C. B. E. M. (2009). Occurrence of methicillin-resistant Staphylococcus aureus in rats living on pig farms. Prev. Vet. Med. 91, 270-273.

van den Broek, I. V., van Cleef, B. A., Haenen, A., Broens, E. M., van der Wolf, P. J., van den Broek, M. J., et al. (2009). Methicillin-resistant Staphylococcus aureus in people living and working in pig farms. Epidemiol. Infect. 137, 700-708.

Van den Eede, A., Martens, A., Feryn, I., Vanderhaeghen, W., Lipinska, U., Gasthuys, F., et al. (2012). Low MRSA prevalence in horses at farm level. BMC Vet. Res. 8:213. doi:10.1186/1746-6148-8-213

Van den Eede, A., Martens, A., Floré, K., Denis, O., Gasthuys, F., Haesebrouck, F., et al. (2013). MRSA carriage in the equine community: an investigation of horsecaretaker couples. Vet. Microbiol. doi:10.1016/j.vetmic.2012.12.038

Van den Eede, A., Martens, A., Lipinska, U., Struelens, M., Deplano, A., Denis, O., et al. (2009). High occurrence of methicillin-resistant Staphylococcus aureus ST398 in equine nasal samples. Vet. Microbiol. 133, 138-144.

van der Mee-Marquet, N., François, P., Domelier-Valentin, A. S., Coulomb, F., Decreux, C., Hombrock-Allet, C., et al. (2011). Emergence of unusual bloodstream infections associated with pig-borne-like Staphylococcus aureus ST398 in France. Clin. Infect. Dis. 52, 152-153.

van der Wolf, P. J., Rothkamp, A., Junker, K., and de Neeling, A. J. (2012). Staphylococcus aureus (MSSA) and MRSA (CC398) isolated from postmortem samples from pigs. Vet. Microbiol. 158, 136-141.

van Duijkeren, E., Ikawaty, R., Broekhuizen-Stins, M. J., Jansen, M. D., Spalburg, E. C., de Neeling, A. J., et al. (2008). Transmission of methicillin-resistant Staphylococcus aureus strains between different kinds of pig farms. Vet. Microbiol. 126, 383-389.

van Duijkeren, E., Jansen, M. D., Flemming, S. C., de, N. H., Wagenaar, J. A., Schoormans, A. H., et al. (2007). Methicillin-resistant Staphylococcus aureus in pigs with exudative epidermitis. Emerg. Infect. Dis. $13,1408-1410$.

van Loo, I., Huijsdens, X., Tiemersma, E., de Neeling, A., Sande-Bruinsma,
N., Beaujean, D., et al. (2007). Emergence of methicillin-resistant Staphylococcus aureus of animal origin in humans. Emerg. Infect. Dis. 13, 1834-1839.

van Rijen, M. M., Bosch, T., Heck, M. E., and Kluytmans, J. A. (2009). Meticillin-resistant Staphylococcus aureus epidemiology and transmission in a Dutch hospital. J. Hosp. Infect. 72, 299-306.

van Rijen, M. M., van Keulen, P. H., and Kluytmans, J. A. (2008). Increase in a Dutch hospital of methicillin-resistant Staphylococcus aureus related to animal farming. Clin. Infect. Dis. 46, 261-263.

Vandendriessche, S., Vanderhaeghen, W., Hermans, K., Haesebrouck, F., Butaye, P., and Denis, O. (2011a). "High prevalence of methicillinresistant Staphylococcus aureus in Belgian veal calf farming," in Proceedings of the 4th Congress of European Microbiologists FEMS. June 2630, Geneva.

Vandendriessche, S., Kadlec, K., Schwarz, S., and Denis, O. (2011b). Methicillin-susceptible Staphylococcus aureus ST398-t571 harbouring the macrolidelincosamide-streptogramin B resistance gene erm(T) in Belgian hospitals. J. Antimicrob. Chemother. 66, 2455-2459.

Vandenesch, F., Naimi, T., Enright, M. C., Lina, G., Nimmo, G. R., Heffernan, H., et al. (2003). Community-acquired methicillinresistant Staphylococcus aureus carrying Panton-Valentine leukocidin genes: worldwide emergence. Emerg. Infect. Dis. 9, 978-984.

Vanderhaeghen, W., Cerpentier, T., Adriaensen, C., Vicca, J., Hermans, K., and Butaye, P. (2010). Methicillin-resistant Staphylococcus aureus (MRSA) ST398 associated with clinical and subclinical mastitis in Belgian cows. Vet. Microbiol. 144, 166-171.

Velebit, B., Fetsch, A., Mirlovic, M., Teodorovic, V., and Jovanovic, M. (2010). MRSA in pigs in Serbia. Vet. Rec. 167, 183-184.

Velthuis, A. G., Bouma, A., Katsma, W. E., Nodelijk, G., and De Jong, M. C. M. (2007). Design and analysis of small-scale transmission experiments with animals. Epidemiol. Infect. 135, 202-217.

Velthuis, A. G., De Jong, M. C. M., Kamp, E. M., Stockhofe, N., and Verheijden, J. H. (2003). Design and analysis of an Actinobacillus pleuropneumoniae transmission experiment. Prev. Vet. Med. 60, 53-68.
Vengust, M., Anderson, M. E., Rousseau, J., and Weese, J. S. (2006). Methicillin-resistant staphylococcal colonization in clinically normal dogs and horses in the community. Lett. Appl. Microbiol. 43, 602-606.

Verhegghe, M., Bekaert, M., Pletinckx, L. J., Crombé, F., Haesebrouck, F., Butaye, P., et al. (2011). "Is there an effect of sow washing on the livestock-associated methicillin-resistant Staphylococcus aureus (MRSA) status or not?" in Proceedings of the Sixteenth Conference on Food Microbiology. Brussels, BE (September 23), p151.

Verhegghe, M., Pletinckx, L. J., Crombé, F., Van Weyenberg, S., Haesebrouck, F., Butaye, P., et al. (2012a). Cohort study for the presence of livestockassociated MRSA in piglets: effect of sow status at farrowing and determination of the piglet colonization age. Vet. Microbiol. 162, 679-686.

Verhegghe, M., Pletinckx, L. J., Crombé, F., Vandersmissen, T., Haesebrouck, F., Butaye, P., et al. (2012b). Methicillin-resistant Staphylococcus aureus (MRSA) ST398 in pig farms and multispecies farms. Zoonoses Public Health doi:10.1111/zph.12007

Verkaik, N. J., de Vogel, C. P., Boelens, H. A., Grumann, D., Hoogenboezem, T., Vink, C., et al. (2009). Antistaphylococcal humoral immune response in persistent nasal carriers and noncarriers of Staphylococcus aureus. J. Infect. Dis. 199, 625-632.

Verkaik, N. J., van Wamel, W. J., and van Belkum, A. (2011). Immunotherapeutic approaches against Staphylococcus aureus. Immunotherapy 3 , 1063-1073.

Vestergaard, M., Cavaco, L. M., Sirichote, P., Unahalekhaka, A., Dangsakul, W., Svendsen, C. A., et al. (2012). SCCmec type IX element in methicillin resistant Staphylococcus aureus spa type t337 (CC9) isolated from pigs and pork in Thailand. Front. Microbiol. 3:103. doi:10.3389/fmicb.2012.00103

Voss, A., Loeffen, F., Bakker, J., Klaassen, C., and Wulf, M. (2005). Methicillinresistant Staphylococcus aureus in pig farming. Emerg. Infect. Dis. 11, 1965-1966.

Wagenaar, J. A., Yue, H., Pritchard, J., Broekhuizen-Stins, M., Huijsdens, X., Mevius, D. J., et al. (2009). Unexpected sequence types in livestock associated methicillinresistant Staphylococcus aureus (MRSA): MRSA ST9 and a single locus variant of ST9 in pig farming in China. Vet. Microbiol. 139, 405-409.

Walther, B., Monecke, S., Ruscher, C., Friedrich, A. W., Ehricht, R., Slickers, P., et al. (2009). Comparative molecular analysis substantiates zoonotic potential of equine methicillin-resistant Staphylococcus aureus. J. Clin. Microbiol. 47, 704-710.

Wassenberg, M. W., Bootsma, M. C., Troelstra, A., Kluytmans, J. A. and Bonten, M. J. (2011). Transmissibility of livestock-associated methicillin-resistant Staphylococcus aureus (ST398) in Dutch hospitals. Clin. Microbiol. Infect. 17, 316-319.

Weese, J. S., Zwambag, A., Rosendal, T., Reid-Smith, R., and Friendship, R. (2011). Longitudinal investigation of methicillin-resistant Staphylococcus aureus in piglets. Zoonoses Public Health 58, 238-243.

Welinder-Olsson, C., Floren-Johansson, K., Larsson, L., Oberg, S., Karlsson, L., and Ahren, C. (2008). Infection with Panton-Valentine leukocidin-positive methicillinresistant Staphylococcus aureus t034. Emerg. Infect. Dis. 14, 1271-1272.

Wertheim, H. F., Melles, D. C., Vos, M. C., van, L. W., van Belkum, A., Verbrugh, H. A., et al. (2005). The role of nasal carriage in Staphylococcus aureus infections. Lancet Infect. Dis. 5, 751-762.

Wertheim, H. F., Vos, M. C., Ott, A., van Belkum, A., Voss, A., Kluytmans, J. A., et al. (2004). Risk and outcome of nosocomial Staphylococcus aureus bacteraemia in nasal carriers versus non-carriers. Lancet 364, 703-705.

Wijaya, L., Hsu, L. Y., and Kurup, A. (2006). Community-associated methicillin-resistant Staphylococcus aureus: overview and local situation. Ann. Acad. Med. Singapore 35, 479-486.

Witte, W. (2009). Community-acquired methicillin-resistant Staphylococcus aureus: what do we need to know? Clin. Microbiol. Infect. 15, $17-25$.

Witte, W., Strommenger, B., Stanek, C., and Cuny, C. (2007). Methicillinresistant Staphylococcus aureus ST398 in humans and animals, Central Europe. Emerg. Infect. Dis. 13, 255-258.

Wulf, M., van Nes, A., EikelenboomBoskamp, A., de Vries, J., Melchers, W., Klaassen, C., et al. (2006). Methicillin-resistant Staphylococcus aureus in veterinary doctors and students, the Netherlands. Emerg. Infect. Dis. 12, 1939-1941. 
Wulf, M. W., Sorum, M., van Nes, A., Skov, R., Melchers, W. J., Klaassen, C. H., et al. (2008a). Prevalence of methicillin-resistant Staphylococcus aureus among veterinarians: an international study. Clin. Microbiol. Infect. 14, 29-34.

Wulf, M. W., Markestein, A., van der Linden, F. T., Voss, A., Klaassen, C., and Verduin, C. M. (2008b). First outbreak of methicillin-resistant Staphylococcus aureus ST398 in a Dutch hospital, June 2007. Euro Surveill. 13. pii: 8051.

Wulf, M. W., Verduin, C. M., van Nes, A., Huijsdens, X., and Voss, A. (2012). Infection and colonization with methicillin resistant Staphylococcus aureus ST398 versus other MRSA in an area with a high density of pig farms. Eur. J. Clin. Microbiol. Infect. Dis. 31, 61-65.
Yamamoto, T., Nishiyama, A., Takano, T., Yabe, S., Higuchi, W., Razvina, O., et al. (2010). Community-acquired methicillin-resistant Staphylococcus aureus: community transmission, pathogenesis, and drug resistance. J. Infect. Chemother. 16, 225-254.

Yao, D., Yu, F. Y., Qin, Z. Q., Chen, C., He, S. S., Chen, Z. Q., et al. (2010). Molecular characterization of Staphylococcus aureus isolates causing skin and soft tissue infections (SSTIs). BMC Infect. Dis. 10:133. doi:10.1186/1471-2334-10133

Yu, F., Chen, Z., Liu, C., Zhang, X., Lin, X., Chi, S., et al. (2008). Prevalence of Staphylococcus aureus carrying Panton-Valentine leukocidin genes among isolates from hospitalised patients in China. Clin. Microbiol. Infect. 14, 381-384.
Zarfel, G., Krziwanek, K., Johler, S., Hoenigl, M., Leitner, E., Kittinger, C., et al. (2012). Virulence and antimicrobial resistance genes in human MRSA ST398 isolates in Austria. Epidemiol. Infect. 13, $1-5$.

Zhang, K., McClure, J. A., Elsayed, S., Louie, T., and Conly, J. M. (2005). Novel multiplex PCR assay for characterization and concomitant subtyping of staphylococcal cassette chromosome mec types I to $\mathrm{V}$ in methicillin-resistant Staphylococcus aureus. J. Clin. Microbiol. 43, 5026-5033.

Conflict of Interest Statement: The authors declare that the research was conducted in the absence of any commercial or financial relationships that could be construed as a potential conflict of interest.
Received: 05 January 2013; accepted: 28 February 2013; published online: 20 March 2013.

Citation: Crombé F, Argudín MA, Vanderhaeghen $W$, Hermans $K$, Haesebrouck $F$ and Butaye $P$ (2013) Transmission dynamics of methicillin-resistant Staphylococcus aureus in pigs. Front. Microbiol. 4:57. doi:10.3389/fmicb.2013.00057

This article was submitted to Frontiers in Antimicrobials, Resistance and Chemotherapy, a specialty of Frontiers in Microbiology.

Copyright (c) 2013 Crombé, Argudin, Vanderhaeghen, Hermans, Haesebrouck and Butaye. This is an open-access article distributed under the terms of the Creative Commons Attribution License, which permits use, distribution and reproduction in other forums, provided the original authors and source are credited and subject to any copyright notices concerning any third-party graphics etc. 